\title{
Distribution of chromium among the octahedral sites in chromian epidote from Iratsu, central Shikoku, Japan
}

\author{
Mariko NAGASHIMA ${ }^{* * *}$, Masahide AKASAKA*, Atsushi KYONO ${ }^{* * *}$, \\ Kuniaki MAKINO $^{* * * *}$ and Ko IKEDA ${ }^{* * * * *}$ \\ *Department of Materials Creation and Circulation Technology, Interdisciplinary Graduate \\ School of Science and Engineering, Shimane University, Matsue 690-8504, Japan \\ ${ }^{* *}$ Present address: Institut für Geowissenschaften, Christian-Albrechts-Universität \\ zu Kiel, 24098 Kiel, Germany \\ **** Division of Earth Evolution Sciences, Graduate School of Life and Environmental Sciences, \\ University of Tsukuba, Tennodai 1-1-1, Tsukuba 305-8572, Japan \\ **** Department of Geology, Shinshu University, Asahi 3-1-1, Matsumoto 390-8621, Japan \\ Department of Advanced Materials Science and Engineering, Yamaguchi University, \\ Tokiwadai 2-16-1, Ube 755-8611, Japan
}

\begin{abstract}
The crystal structures of chromian epidotes from the Sambagawa metamorphic rocks, central Shikoku, Japan, were refined using single-crystal data to investigate the distribution of chromium among the three independent octahedral sites. On the basis of the electron probe microanalysis of the chromian epidotes on the polished surface of thin sections, three chromian epidote grains in a thin section were selected for X-ray intensity data collection, and their $\mathrm{Cr}_{2} \mathrm{O}_{3}$ values were as much as $1.79,4.99$, and $4.74 \mathrm{wt} \%$, respectively, which led to values of $0.113,0.315$, and $0.299 \mathrm{Cr}$ apfu, respectively. Nevertheless, their $\mathrm{Fe}_{2} \mathrm{O}_{3}$ contents were nearly constant (8.1-8.7 wt $\%, 0.49-0.52 \mathrm{Fe}$ apfu) and their SrO contents were not significant (1.8-3.2 wt\%, 0.08-0.15 Sr apfu). The selected chromian epidote grains were picked out using a binocular optical microscope from the thin sections, and were labeled as CrEp1, CrEp2, and CrEp3, respectively. The oxidation state of chromium was found to be trivalent by the optical spectrum. ${ }^{57} \mathrm{Fe}$ Mössbauer doublets with isomer shift of $0.28-0.53 \mathrm{~mm} / \mathrm{sec}$ and quadrupole splitting of 1.77-2.24 mm/sec indicate an exclusive distribution of $\mathrm{Fe}^{3+}$ at the $M 3$ site. The crystal structure of CrEp1 $\left[a=8.8815(6), b=5.5956(5), c=10.1532(5) \AA, \beta=115.159(2)^{\circ}\right], \operatorname{CrEp} 2[a=8.9165(4), b=5.6226(2)$, $\left.c=10.1728(5) \AA, \beta=115.2365(9)^{\circ}\right]$, and CrEp3 $\left[a=8.895(2), b=5.610(1), c=10.146(2) \AA, \beta=115.177(2)^{\circ}\right]$ were refined using 1145, 1853 and 1438 unique reflections, respectively, and the calculations converged at $R$ factors of $5.8 \%, 6.6 \%$, and $3.2 \%$, respectively. The resulting structural formula were: $[\mathrm{Ca}]^{A 1}\left[\mathrm{Ca}_{0.86} \mathrm{Sr}_{0.14}\right]^{A 2}[\mathrm{Al}]^{M 1}$ $[\mathrm{Al}]^{M 2}\left[\mathrm{Al}_{0.43} \mathrm{Cr}_{0.09}^{3+} \mathrm{Fe}_{0.48}^{3+}\right]^{M 3} \mathrm{Si}_{3} \mathrm{O}_{12}(\mathrm{OH})$ for $\mathrm{CrEpl},[\mathrm{Ca}]^{A 1}\left[\mathrm{Ca}_{0.90} \mathrm{Sr}_{0.10}\right]^{A 2}\left[\mathrm{Al}_{0.86} \mathrm{Cr}_{0.14}^{3+}\right]^{M 1}[\mathrm{Al}]^{M 2}\left[\mathrm{Al}_{0.34} \mathrm{Cr}_{0.17}^{3+} \mathrm{Fe}_{0.49}^{3+}\right]^{M 3} \mathrm{Si}_{3} \mathrm{O}_{12}$ $(\mathrm{OH})$ for $\mathrm{CrEp} 2$, and $[\mathrm{Ca}]^{A 1}\left[\mathrm{Ca}_{0.88} \mathrm{Sr}_{0.12}\right]^{A 2}\left[\mathrm{Al}_{0.90} \mathrm{Cr}_{0.10}^{3+}\right]^{M 1}[\mathrm{Al}]^{M 2}\left[\mathrm{Al}_{0.37} \mathrm{Cr}_{0.12}^{3+} \mathrm{Fe}_{0.51}^{3+}\right]^{M 3} \mathrm{Si}_{3} \mathrm{O}_{12}(\mathrm{OH})$ for $\mathrm{CrEp} 3$. The selective distribution of $\mathrm{Cr}^{3+}$ at the $M 3$ site in $\mathrm{CrEp} 1$, and the $K_{\mathrm{D}}$ values $\left(K_{\mathrm{D}}=\left(\mathrm{Cr}^{3+} / \mathrm{Al}\right)^{M 1} /\left(\mathrm{Cr}^{3+} / \mathrm{Al}\right)^{M 3}\right)$ of $0.35(3)$ for CrEp2 and 0.41(3) for CrEp3 show that the preference of $\mathrm{Cr}^{3+}$ in the octahedral sites is $M 3>M 1 \gg M 2$. The variations in the $M 1^{-} \mathrm{O} i$ and $M 3^{-} \mathrm{O} i$ distances indicate an equidimensional expansion of the $M 1 \mathrm{O}_{6}$ and $M 3 \mathrm{O}_{6}$ octahedra by the substitution of $\mathrm{Cr}^{3+}\left(+\mathrm{Fe}^{3+}\right)$ for $\mathrm{Al}^{3+}$.
\end{abstract}

Keywords: Epidote, Chromium, Crystal structure, X-ray, Mössbauer, Optical spectroscopy

\section{INTRODUCTION}

Epidote group minerals with the formula $A 1 A 2 M 1 M 2 M 3$ $\mathrm{Z}_{3} \mathrm{O}_{12}(\mathrm{OH})$ belong to the sorosilicate class, and their struc-

doi:10.2465/jmps.060310

M. Nagashima, s039703@riko.shimane-u.ac.jp Corresponding author

M. Akasaka, akasaka@riko.shimane-u.ac.jp

A. Kyono,kyono@arsia.geo.tsukuba.ac.jp

K. Makino,makinox@gipac.shinshu-u.ac.jp ture is based on a single chain of $M 2$ octahedra and multiple chains of central $M 1$ and peripheral $M 3$ octahedra parallel to the $b$ axis, linked by independent $\mathrm{SiO}_{4}$ and $\mathrm{Si}_{2} \mathrm{O}_{7}$ groups (Ito et al., 1954; Dollase, 1968). In calcium epidote, $\mathrm{Ca}^{2+}$ cations occupy 9-coordinated $A 1$ and $10^{-}$-coordinated $A 2$ sites, trivalent cations, such as $\mathrm{Al}^{3+}, \mathrm{Fe}^{3+}$, $\mathrm{Mn}^{3+}$, and $\mathrm{Cr}^{3+}$, are distributed among the octahedral $M 1$, $M 2$ and $M 3$ sites, and $\mathrm{Si}$ cations occur in the tetrahedral $Z$ sites.

The distribution of $\mathrm{Fe}^{3+}$ and $\mathrm{Mn}^{3+}$ in calcium epidote 
members and the effect on their crystal structures have been investigated by means of structural analysis (Dollase, 1969, 1971; Kvick et al., 1988; Ferraris et al., 1989; Bonazzi et al., 1990, 1992; Bonazzi and Menchetti, 1994, 1995; Langer et al., 2002; Nagashima and Akasaka, 2004; and others) and a variety of spectroscopic methods (Burns and Strens, 1967; Dollase, 1973; Paesano et al., 1983; Fehr and Heuss-Aßbichler, 1997; Langer et al., 2002; and others). On the other hand, the distribution of $\mathrm{Cr}^{3+}$ has been studied by means of optical spectroscopy (Burns and Strens, 1967), but the structural refinement of chromian epidote has not been carried out so far, because the occurrence of chromian epidote is not common.

Recently, Nagashima et al. (2006) reported on the occurrence of chromian epidote containing up to $6 \mathrm{wt} \%$ $\mathrm{Cr}_{2} \mathrm{O}_{3}$ in pebbles of omphacite rock from the Sambagawa metamorphic rocks in central Shikoku, Japan. In the present study, we have investigated the structure of chromian epidote obtained using single-crystal X-ray diffraction coupled with ${ }^{57} \mathrm{Fe}$ Mössbauer spectroscopy and optical spectroscopy.

\section{EXPERIMENTAL METHODS}

\section{Samples}

The chromian epidote studied occurs in omphacite rock pebbles obtained from the Sambagawa metamorphic rocks in central Shikoku, Japan. Nagashima et al. (2006) distinguished three types of chromian epidote: $\mathrm{Ca}^{-}$epidote with $<3 \mathrm{wt} \%$ SrO, Sr-rich epidote with 3-11 wt\% $\mathrm{SrO}$, and the rare-earth elements (REE)-rich epidote with 2-7 wt $\%\left(\mathrm{Ce}_{2} \mathrm{O}_{3}+\mathrm{La}_{2} \mathrm{O}_{3}+\mathrm{Nd}_{2} \mathrm{O}_{3}+\mathrm{Pr}_{2} \mathrm{O}_{3}+\mathrm{Sm}_{2} \mathrm{O}_{3}+\right.$ $\mathrm{Gd}_{2} \mathrm{O}_{3}$ ), and described the cores of the Sr-rich epidote being overgrown with $\mathrm{Ca}$-epidote, whereas the $\mathrm{Ca}$-epidotes were rimmed by and/or intergrown with REE-rich epidotes. The $\mathrm{Cr}_{2} \mathrm{O}_{3}$ content in the epidote is variable and attains up to $6 \mathrm{wt} \%$ around the chromite grains. The Cr distribution is not related to any zonal structure. The $\mathrm{Fe}^{3+}$ content varies within a narrow range: 5-7 or 6-9 wt\% of the total $\mathrm{Fe}_{2} \mathrm{O}_{3}$ (Nagashima et al., 2006).

In order to analyze the oxidation state of the iron and chromium using ${ }^{57} \mathrm{Fe}$ Mössbauer spectroscopy and optical spectroscopy, respectively, the chromian epidote was separated from the omphacite rock pebbles using the following procedure. The pebbles were manually crushed down to grains $0.25-0.5 \mathrm{~mm}$ in diameter, and the chromian epidote grains were then separated using a Franz isodynamic separator. They were further purified by handpicking under an optical microscope, and the separated grains were crushed to produce grains with $100-150 \mu \mathrm{m}$ in diameter. The samples obtained were purified once again using the isodynamic separation and handpicking procedures. Finally, about $200 \mathrm{mg}$ of the chromian epidote grains were collected and ground using an agate mortar to produce a powdered sample. The purity of the powdered sample was examined using X-ray powder diffraction method.

For the single-crystal structural analysis of the chromian epidote, chemically homogeneous crystals or grains were searched for on the polished surface of thin sections by use of the element concentration and quantitative analysis using a JEOL JXA-8800M electron probe microanalyzer (EPMA). The details of the analytical conditions of the EPMA analysis have been described in Nagashima et al. (2006). Finally, three chromian epidote grains with relatively high $\mathrm{Cr}_{2} \mathrm{O}_{3}$ content were selected for X-ray data collection. They were picked out under a binocular optical microscope from a thin section of Sample 2, as described in Nagashima et al. (2006). The samples obtained were labeled as $\mathrm{CrEp} 1, \mathrm{CrEp} 2$, and $\mathrm{CrEp} 3$ and had dimensions of $0.20 \times 0.40 \times 0.20,0.20 \times 0.20 \times 0.20$, and $0.50 \times 0.40 \times 0.10 \mathrm{~mm}^{3}$, respectively.

\section{X-ray powder diffraction}

A part of the powdered sample was spread uniformly over the surface of a silicon non-reflection specimen holder. Step scan powder diffraction data were collected using a Rigaku RINT automated Bragg-Brentano diffractometer system equipped with a curved graphite diffracted-beam monochromator. The $\mathrm{Cu} \mathrm{X}$-ray tube generator was operated at $35 \mathrm{kV}$ and $20 \mathrm{~mA}$. The X-ray powder diffraction profile was taken between $5^{\circ}$ and $120^{\circ}$ in $2 \theta$ using a step interval of $0.02^{\circ}$ and a step count time of 5 seconds.

To evaluate the purity of the powdered sample, the powder diffraction data was analyzed using the RIETAN2000 program (Izumi and Ikeda, 2000). The peaks were defined using a modified split pseudo-Voigt function implemented by (Izumi and Ikeda, 2000). The asymmetry parameter was built into this profile function. The preferred orientation was corrected with the March-Dollase function (Dollase, 1986).

\section{${ }^{57}$ Fe Mössbauer spectroscopy}

The ${ }^{57} \mathrm{Fe}$ Mössbauer spectrum of the chromian epidote samples (about $150 \mathrm{mg}$ of powder) was measured at 298 $\mathrm{K}$ using $370 \mathrm{MBq}{ }^{57} \mathrm{Co}$ in $\mathrm{Pd}$ as the $\gamma$-ray source. The Mössbauer data were obtained using a constant acceleration spectrometer fitted with a 1024-channel analyzer. The isomer shift $(I S)$ was referenced to a metallic iron foil. The Doppler velocity was calibrated using the same metallic iron foil. The QBMOSS program of Akasaka and Shinno (1992) was used for the least-squares calcula- 
tion of the spectrum. The spectrum was fitted to Lorentzians with the line widths and intensities constrained to be equal at each site. The quality of the fit was judged from the $\chi^{2}$ value and the standard deviation of the Mössbauer parameters.

\section{Optical spectroscopy}

The unpolarized optical spectrum of the chromian epidote was measured in the wavelength range from $280 \mathrm{~nm}$ to $840 \mathrm{~nm}$ for the powder sample at room temperature using a Hitachi U-3500 optical spectrometer. The powder sample was densely mounted in a glass sample holder with a $20 \times 18 \times 1.5 \mathrm{~mm}^{3}$ cavity. The diffuse reflectance from 0 to $100 \%$ was measured using an integrating sphere.

\section{Single crystal structural analysis}

The diffraction data of the chromian epidotes were collected using a Rigaku RAXIS RAPID imaging plate (IP) diffractometer of the University of Tsukuba for CrEp1 and CrEp2, and a Bruker SMART APEX CCD diffractometer of Bruker AXS K.K. for CrEp3.

For CrEp1 and CrEp2, a block crystal was mounted on a glass fiber, and the intensity data were collected at room temperature using graphite monochromatized Mo $K \alpha$ radiation $(\lambda=0.71069 \AA)$. A total of 88 oscillation images were collected. A sweep of the data was done using $\omega$ scans in $5.0^{\circ}$ steps from 130.0 to $190.0^{\circ}$ for $\chi=45.0$ ${ }^{\circ}$ and $\varphi=0.0^{\circ}$, and from 0.0 to $160.0^{\circ}$ for $\chi=45.0^{\circ}$ and $\varphi$ $=180.0^{\circ}$. Another sweep was performed using $\varpi$ scans in 5.0 ${ }^{\circ}$ steps from 130.0 to $190.0^{\circ}$ for $\chi=45.0^{\circ}$ and $\varphi=90.0^{\circ}$ and from 0.0 to $160.0^{\circ}$ for $\chi=45.0^{\circ}$ and $\varphi=270.0^{\circ}$. The exposure rate was 120 seconds per degree. Equivalent reflections were merged using the PROCESS-AUTO program package. The data were corrected for Lorentz and polarization effects. A symmetry-related empirical absorption correction using the ABSCOR program (Higashi, 1995) was applied.

The single crystal of CrEp3 was mounted on a glass fiber and positioned in the CCD diffractometer equipped with a cryo-stream liquid nitrogen cryostat. Preliminary lattice parameters and an orientation matrix were obtained from three sets of frames and refined during the integration process of the intensity data. The intensity data were measured using graphite-monochromatized MoKa radiation. Diffraction data were collected at $90 \mathrm{~K}$ using multiple $\varpi$ scans with different $\varphi$ settings (i.e., $\varphi$ and $\varpi$ scans) (Bruker, 1999). The data were processed using the SAINT (Bruker, 1999). An empirical absorption correction using the SADABS (Sheldrick, 1996) was ap- plied. The structure was solved using direct methods employing the SHELXS97 program (Sheldrick, 1997) with default parameters, and expanded using Fourier techniques. Structural refinement was performed using the SHELXL97 program (Sheldrick, 1997). The scattering factors of the neutral atoms were employed in our analysis. First, several refinement cycles were carried out using the isotropic thermal displacement parameters for the nonhydrogen atoms, and then, refinement using the anisotropic thermal displacement parameters was made.

\section{RESULTS}

\section{Chemical compositions of specimen}

Table 1 shows the results of the chemical analyses for the three chromian epidote grains in the thin section from which CrEp1, CrEp2, and CrEp3 were picked out. As described below, the Mössbauer and optical spectroscopy studies revealed all the $\mathrm{Fe}$ and $\mathrm{Cr}$ to be trivalent in oxidation state. The oxidation state of $\mathrm{Mn}$ is regarded as divalent, because the chromian epidote is associated with $\mathrm{Fe}^{2+}$-bearing phases such as omphacite, amphibole, and mica (Nagashima et al., 2006) and $\mathrm{Mn}^{2+}$ is the most stable manganese cation under the $f_{\mathrm{O}_{2}}$ conditions where both $\mathrm{Fe}^{2+}$ and $\mathrm{Fe}^{3+}$ exist. The $\mathrm{Cr}_{2} \mathrm{O}_{3}$ contents of the chromian epidote grains corresponding to $\mathrm{CrEp} 1, \mathrm{CrEp} 2$, and $\mathrm{CrEp} 3$ are $1.79,4.99$, and $4.74 \mathrm{wt} \%$, respectively. The $\mathrm{Fe}_{2} \mathrm{O}_{3}$ content is nearly constant $(8.12-8.67 \mathrm{wt} \%)$. The $\mathrm{SrO}$ content ranges from 1.79 to $3.15 \mathrm{wt} \%$. A very small amount of REE is also present.

In Table $1, \mathrm{Fe}^{3+}$ and $\mathrm{Cr}^{3+}$ are allocated to the octahedral sites based on the spectroscopic studies. The distribution of $\mathrm{V}^{3+}$ at the octahedral sites in epidotes has been confirmed in mukhinite (Shepel and Karpenko, 1969), and $\mathrm{Ti}^{4+}$ has been considered to occupy the octahedral sites (Franz and Liebscher, 2004). Thus, both V and Ti are assigned to the octahedral sites. The deficiency of $\mathrm{Ca}$ in the $A$ position is made up for by $\mathrm{Sr}^{2+}, \mathrm{Mn}^{2+}$, and $\mathrm{Mg}^{2+}$ (Bonazzi et al., 1990; Akasaka et al., 2000; Armbruster et al., 2002; Miyajima et al., 2003; Bonazzi and Menchetti, 2004).

\section{Purity of the powder sample}

The X-ray powder diffraction pattern showed that the powder sample consists of not only epidote but also a very small amount of omphacite. By applying the reported structural parameters of epidote (Dollase, 1971) and omphacite (Mottana et al., 1979) as the initial structural parameters, the mass fractions of epidote and omphacite in the powder sample were readily obtained from ordinary 
Table 1. Chemical compositions of the chromian epidotes

\begin{tabular}{|c|c|c|c|}
\hline Sample No. & CrEp 1 & CrEp 2 & CrEp 3 \\
\hline $\mathrm{SiO}_{2}$ & 37.08 & 36.77 & 37.05 \\
\hline $\mathrm{TiO}_{2}$ & 0.13 & 0.16 & 0.09 \\
\hline $\mathrm{Al}_{2} \mathrm{O}_{3}$ & 26.74 & 24.26 & 23.99 \\
\hline $\mathrm{Cr}_{2} \mathrm{O}_{3}{ }^{*}$ & 1.79 & 4.99 & 4.74 \\
\hline $\mathrm{Fe}_{2} \mathrm{O}_{3 * *}{ }^{*}$ & 8.12 & 8.28 & 8.67 \\
\hline $\mathrm{V}_{2} \mathrm{O}_{3}^{* *}$ & 0.00 & 0.04 & 0.00 \\
\hline $\mathrm{MnO}^{* *}$ & 0.09 & 0.10 & 0.02 \\
\hline $\mathrm{MgO}$ & 0.06 & 0.09 & 0.06 \\
\hline $\mathrm{CaO}$ & 20.45 & 21.87 & 21.81 \\
\hline $\mathrm{SrO}$ & 3.15 & 1.79 & 1.80 \\
\hline $\mathrm{BaO}$ & 0.06 & 0.00 & 0.00 \\
\hline $\mathrm{Na}_{2} \mathrm{O}$ & 0.01 & 0.04 & 0.02 \\
\hline $\mathrm{K}_{2} \mathrm{O}$ & 0.04 & 0.03 & 0.00 \\
\hline $\mathrm{La}_{2} \mathrm{O}_{3}$ & 0.03 & 0.06 & 0.07 \\
\hline $\mathrm{Ce}_{2} \mathrm{O}_{3}$ & 0.11 & 0.04 & 0.15 \\
\hline $\mathrm{Pr}_{2} \mathrm{O}_{3}$ & 0.10 & 0.00 & 0.00 \\
\hline $\mathrm{Nd}_{2} \mathrm{O}_{3}$ & 0.00 & 0.00 & 0.00 \\
\hline $\mathrm{Sm}_{2} \mathrm{O}_{3}$ & 0.10 & 0.08 & 0.03 \\
\hline $\mathrm{Eu}_{2} \mathrm{O}_{3}$ & 0.02 & 0.01 & 0.00 \\
\hline $\mathrm{Gd}_{2} \mathrm{O}_{3}$ & 0.00 & 0.02 & 0.00 \\
\hline Total & 98.08 & 98.63 & 98.50 \\
\hline \multicolumn{4}{|c|}{ Cations per 12.5 oxygens } \\
\hline $\mathrm{Si}$ & 2.952 & 2.932 & 2.955 \\
\hline $\mathrm{Al}$ & 0.048 & 0.068 & 0.045 \\
\hline$\Sigma$ & 3.000 & 3.000 & 3.000 \\
\hline $\mathrm{Ti}$ & 0.008 & 0.010 & 0.005 \\
\hline $\mathrm{Al}$ & 2.462 & 2.212 & 2.210 \\
\hline $\mathrm{Cr}^{3+}$ & 0.113 & 0.315 & 0.299 \\
\hline $\mathrm{Fe}^{3+}$ & 0.487 & 0.497 & 0.521 \\
\hline $\mathrm{V}^{3+}$ & 0.000 & 0.003 & 0.000 \\
\hline$\Sigma$ & 3.070 & 3.037 & 3.035 \\
\hline $\mathrm{Mn}^{2+}$ & 0.006 & 0.006 & 0.001 \\
\hline $\mathrm{Mg}$ & 0.008 & 0.010 & 0.007 \\
\hline $\mathrm{Ca}$ & 1.745 & 1.869 & 1.863 \\
\hline $\mathrm{Sr}$ & 0.145 & 0.083 & 0.083 \\
\hline $\mathrm{Ba}$ & 0.002 & 0.000 & 0.000 \\
\hline $\mathrm{Na}$ & 0.001 & 0.006 & 0.002 \\
\hline K & 0.004 & 0.003 & 0.000 \\
\hline $\mathrm{La}$ & 0.003 & 0.002 & 0.002 \\
\hline $\mathrm{Ce}$ & 0.000 & 0.001 & 0.004 \\
\hline $\operatorname{Pr}$ & 0.003 & 0.000 & 0.000 \\
\hline $\mathrm{Nd}$ & 0.001 & 0.000 & 0.000 \\
\hline $\mathrm{Sm}$ & 0.000 & 0.002 & 0.001 \\
\hline $\mathrm{Eu}$ & 0.000 & 0.000 & 0.000 \\
\hline $\mathrm{Gd}$ & 0.000 & 0.001 & 0.000 \\
\hline$\Sigma$ & 1.918 & 1.983 & 1.963 \\
\hline
\end{tabular}

* Oxydation states of $\mathrm{Fe}$ and $\mathrm{Cr}$ were determined by ${ }^{57} \mathrm{Fe}$ Mössbauer and optical spectroscopy, respectively.

** Total $\mathrm{V}$ and $\mathrm{Mn}$ as $\mathrm{V}_{2} \mathrm{O}_{3}$ and $\mathrm{MnO}$, respectively.
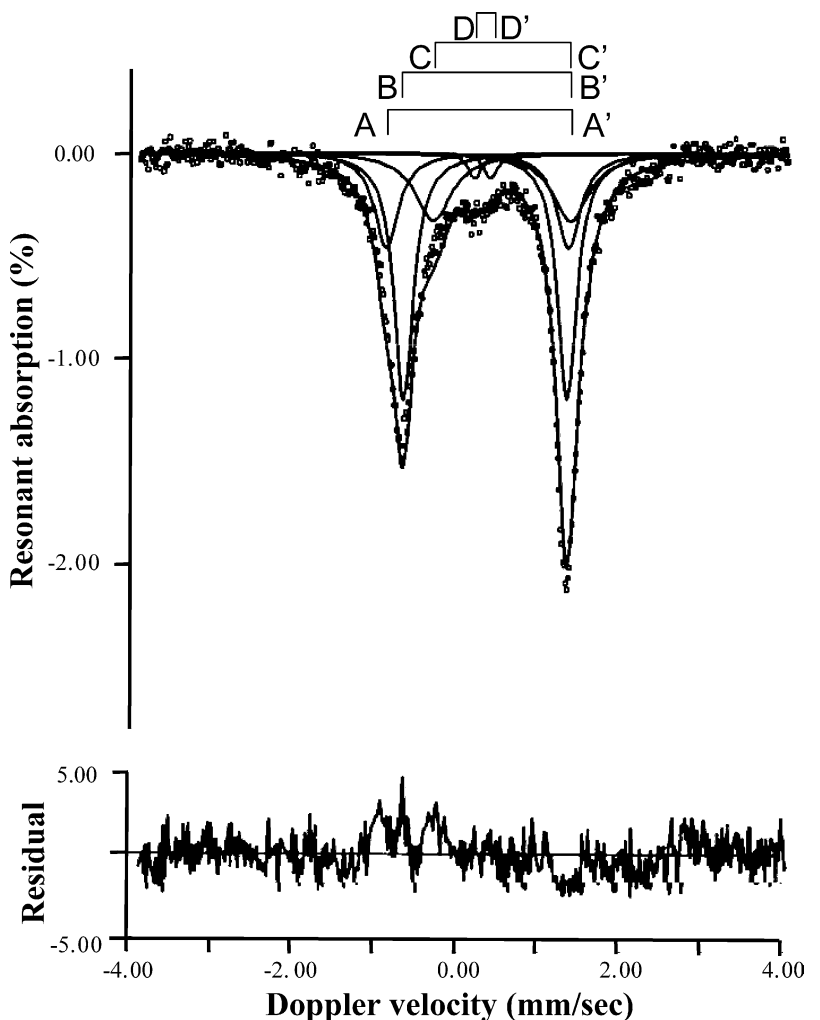

Figure 1. ${ }^{57} \mathrm{Fe}$ Mössbauer spectrum of the chromian epidote at 298 $\mathrm{K}$. The refined Mössbauer parameters are listed in Table 2.

Rietveld analysis where the atomic positions and isotropic atomic displacement parameters were fixed to those of the initial values in the present refinement. The converged mass fractions of epidote and omphacite are 0.99 and 0.01 , respectively, and the unit cell parameters were refined as follows: $a=8.882(7), b=5.604(3), c=10.161(8) \AA, \beta=$ 115.32(4) ${ }^{\circ}$, and $V=457.2(6) \AA^{3}$ for the epidote $\left(P 2_{1} / m\right)$, and $a=9.59(2), b=8.779(7), c=5.255(6) \AA, \beta=107.1(1)^{\circ}$, and $V=423(1) \AA^{3}$ for the omphacite $(P 2 / n)$. The values of $R_{\text {wp }}$ and $R_{\mathrm{e}}$ were 16.47 and 9.42, respectively, and thus, the goodness-of-fit was 1.748 .

\section{Mössbauer spectroscopy}

The ${ }^{57} \mathrm{Fe}$ Mössbauer spectrum consists of three main doublets $\left(\mathrm{AA}^{\prime}, \mathrm{BB}^{\prime}\right.$, and $\left.\mathrm{CC}^{\prime}\right)$ and one very small doublet (DD') (Fig. 1). The hyperfine parameters are listed in Table 2. In ${ }^{57} \mathrm{Fe}$ Mössbauer studies on epidote, the doublets with $I S=$ 0.22 to $0.36 \mathrm{~mm} / \mathrm{sec}$ and quadrupole splitting $(Q S)=1.46$ to $1.67 \mathrm{~mm} / \mathrm{sec}$, and those with $I S=0.31$ to $0.44 \mathrm{~mm} / \mathrm{sec}$ and $Q S=1.89$ to $2.32 \mathrm{~mm} / \mathrm{sec}$ have been assigned to $\mathrm{Fe}^{3+}$ at the $M 1$ and $M 3$ sites, respectively (Bancroft et al., 1967; Dollase, 1973; Bird et al., 1988; Fehr and Heuss-Aßbichler, 1997; Heuss-Aßbichler and Fehr, 2000; Liebscher, 2004). Thus, the doublets $\mathrm{AA}^{\prime}$ and $\mathrm{BB}^{\prime}$ can be assigned to $\mathrm{Fe}^{3+}$ at the $M 3$ site in epidote. The hyperfine parameters 
Table 2. ${ }^{57} \mathrm{Fe}$ Mössbauer hyperfine parameters ${ }^{*}$ and assignments

\begin{tabular}{llllll}
\hline Doublet & $I S(\mathrm{~mm} / \mathrm{s})$ & $Q S(\mathrm{~mm} / \mathrm{s})$ & $\Gamma(\mathrm{mm} / \mathrm{s})$ & Area Ratio $(\%)$ & Assignment \\
\hline AA' $^{\prime}$ & $0.28(4)$ & $2.24(9)$ & $0.37(4)$ & $25(5)$ & $\mathrm{Fe}^{3+}(\mathrm{M} 3)$ in epidote \\
BB' $^{\prime}$ & $0.366(8)$ & $2.01(2)$ & $0.28(2)$ & $46(6)$ & $\mathrm{Fe}^{3+}(\mathrm{M} 3)$ in epidote \\
$\mathrm{CC}^{\prime}$ & $0.53(4)$ & $1.77(9)$ & $0.49(5)$ & $24(4)$ & $\mathrm{Fe}^{3+}(\mathrm{M} 3)$ in epidote (allanite) \\
DD' $^{\prime}$ & $0.31(1)$ & $0.21(3)$ & $0.26(6)$ & $5(1)$ & $\mathrm{Fe}^{3+}$ in omphacite \\
\hline
\end{tabular}

${ }^{*} I S$, isomer shift referred to metallic iron absorber; $Q S$, quadrupole splitting; $\Gamma$, Line width. $\chi^{2} /$ Freedom $=1.56$.

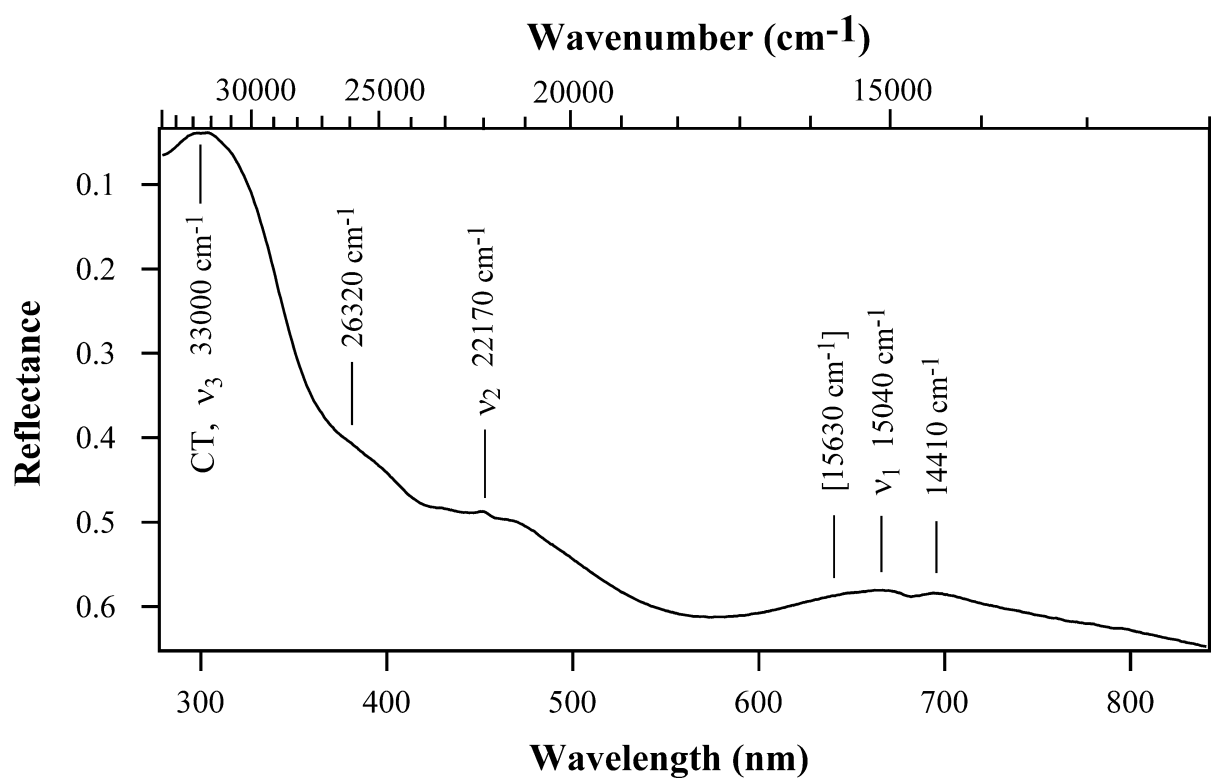

Figure 2. Crystal-field spectrum of the chromian epidote. The assignment of the spectrum peaks and crystal-field parameters are listed in Table 3.

of the doublet $\mathrm{CC}^{\prime}(I S=0.53 \mathrm{~mm} / \mathrm{sec}, Q S=1.77 \mathrm{~mm} / \mathrm{sec})$ correspond to $\mathrm{Fe}^{3+}$ at the $M 3$ site in allanite with $I S=0.37$ to $0.55 \mathrm{~mm} / \mathrm{sec}$ and $Q S=1.61$ to $2.00 \mathrm{~mm} / \mathrm{sec}$ (Liebscher, 2004). The existence of a couple of doublets of $\mathrm{Fe}^{3+}$ at the $M 3$ site with a slightly different $Q S$ can be attributed to the heterogeneous chemical composition of the chromian epidotes in the Mössbauer sample, which consists of not only chromian $\mathrm{Ca}^{-}$-epidote but also $\mathrm{Sr}$-rich epidote and REE-rich epidote (Nagashima et al., 2006).

The $Q S$ of $0.21 \mathrm{~mm} / \mathrm{sec}$ of the doublet $\mathrm{DD}^{\prime}$ does not agree with that of $\mathrm{Fe}^{3+}$ at the $M 1$ and $M 3$ sites in epidote. Nevertheless, the hyperfine parameters of the doublet DD' are similar to those of $\mathrm{Fe}^{3+}$ in sodic pyroxene $(Q S=0.29$ to $0.55 \mathrm{~mm} / \mathrm{sec}$ : Bancroft and Williams, 1969; Aldridge et al., 1978; Dollase and Gustafson, 1982), which was inevitably contaminated during the separation of the chromian epidote.

\section{Optical spectroscopy}

Since the measured diffuse reflectance spectrum of the chromian epidote was very low in intensity, the conversion spectrum to absorption scale by applying the Kubelka-Munk formula was much lower in intensity. Therefore, the reflectance spectrum was directly plotted against wavelength and wave number scales, as shown in Figure 2. The assignment of the peaks in the spectrum and the crystal-field parameters are listed in Table 3.

Five discrete bands were assigned in the spectrum. Four of them centered at $33000\left(v_{3}\right), 22170\left(v_{2}\right), 15040\left(v_{1}\right)$ and $14410 \mathrm{~cm}^{-1}$ are attributed to $\mathrm{Cr}^{3+}$ of the quartet state, and the other band centered at $26320 \mathrm{~cm}^{-1}$ to $\mathrm{Fe}^{3+}$ of the sextet state (Bates, 1962). The band at $v_{3}$ is duplicated with a charge transfer band occurring between the central metal and the legends. The broadened band of $\mathrm{Cr}^{3+}$ centered at the $v_{2}$ position is overlapped with a relatively sharp band of $\mathrm{Fe}^{3+}$. Another spin-forbidden band of ${ }^{2} \mathrm{~T}_{1 \mathrm{~g}}(\mathrm{G}) \leftarrow{ }^{4} \mathrm{~A}_{2 \mathrm{~g}}(\mathrm{~F})$ for $\mathrm{Cr}^{3+}$ is not clearly observed, but it is estimated to be at $15630 \mathrm{~cm}^{-1}$ by calculation. The two main $v_{1}$ and $v_{2}$ absorption bands belonging to spin-allowed transitions of $\mathrm{Cr}^{3+}$ show $10 \mathrm{Dq}=15040 \mathrm{~cm}^{-1}$ and $\mathrm{B}$ $=767 \mathrm{~cm}^{-1}$, respectively. From the spin-forbidden transi- 
Table 3. Assignments of the spectrum peaks to the transitions and crystal field parameters of the chromian epidote

\begin{tabular}{|c|c|c|c|c|c|}
\hline No. & $\begin{array}{l}\text { Wavelength } \\
(\mathrm{nm})\end{array}$ & $\begin{array}{l}\text { Wavenumber } \\
\left(\mathrm{cm}^{-1}\right)\end{array}$ & $\begin{array}{l}\text { Octahedral } \\
\text { ion species }\end{array}$ & Assignment: $\mathrm{Cr}^{3+}$ & Assignment: $\mathrm{Fe}^{3+}$ \\
\hline 1 & 303 & 33000 & $\mathrm{Cr}^{3+}$ & $v_{3}:{ }^{4} \mathrm{~T}_{1 \mathrm{~g}}(\mathrm{P}) \leftarrow{ }^{4} \mathrm{~A}_{2 \mathrm{~g}}(\mathrm{~F}), \mathrm{CT}^{*}$ & $\mathrm{CT}^{*}$ \\
\hline 2 & 380 & 26320 & $\mathrm{Fe}^{3+}$ & & ${ }^{4} E_{g}(D) \leftarrow{ }^{6} A_{1 g}(S)$ \\
\hline $3^{* *}$ & 451 & 22170 & $\mathrm{Cr}^{3+}, \mathrm{Fe}^{3+* *}$ & $v_{2}:{ }^{4} \mathrm{~T}_{1 \mathrm{~g}}(\mathrm{~F}) \leftarrow{ }^{4} \mathrm{~A}_{2 \mathrm{~g}}(\mathrm{~F})$ & ${ }^{4} \mathrm{~A}_{1 \mathrm{~g}},{ }^{4} \mathrm{E}_{\mathrm{g}}(\mathrm{G}) \leftarrow{ }^{6} \mathrm{~A}_{1 \mathrm{~g}}(\mathrm{~S})$ \\
\hline $4^{* * *}$ & [640] & [15630] & $\mathrm{Cr}^{3+}$ & ${ }^{2} \mathrm{~T}_{1 \mathrm{~g}}(\mathrm{G}) \leftarrow{ }^{4} \mathrm{~A}_{2 \mathrm{~g}}(\mathrm{~F})$ & \\
\hline 5 & 665 & 15040 & $\mathrm{Cr}^{3+}$ & $v_{1}:{ }^{4} \mathrm{~T}_{2 \mathrm{~g}}(\mathrm{~F}) \leftarrow{ }^{4} \mathrm{~A}_{2 \mathrm{~g}}(\mathrm{~F})$ & \\
\hline 6 & 694 & 14410 & $\mathrm{Cr}^{3+}$ & ${ }^{2} E_{g}(G) \leftarrow{ }^{4} A_{2 g}(F)$ & \\
\hline \multicolumn{6}{|c|}{ Crystal field parameters of $\mathrm{Cr}^{3+}$} \\
\hline \multicolumn{2}{|c|}{$10 \mathrm{Dq}$} & 15040 & & & \\
\hline \multicolumn{2}{|l|}{ B } & 767 & & & \\
\hline \multicolumn{2}{|l|}{$\mathrm{C}$} & 2960 & & & \\
\hline
\end{tabular}

tion, the value of $\mathrm{C}$ was determined to be $2960 \mathrm{~cm}^{-1}$. Since the spin-allowed transition of free $\mathrm{Cr}^{3+}$ has $\mathrm{B}=810$ $\mathrm{cm}^{-1}$, the ionic character of the $\mathrm{Cr}^{3+}-\mathrm{O}$ bond in the chromian epidote is $95 \%$. The crystal field of the octahedral site is slightly weaker than that of kosmochlor $\left(\mathrm{NaCrSi}_{2} \mathrm{O}_{6}\right)$ having $10 \mathrm{Dq}=15600 \mathrm{~cm}^{-1}, \mathrm{~B}=646 \mathrm{~cm}^{-1}$ (White et al., 1971), and a mean $M^{-} \mathrm{O}$ bond distance of $1.998 \AA$ (Clark et al., 1969). Subsequently, the mean $M-O$ distance around the octahedral $\mathrm{Cr}^{3+}$ ions of the chromian epidote was calculated using the formula, $\Delta / \Delta^{\prime}=\left(R^{\prime} / R\right)^{5}$ (White et al., 1971), where $\Delta$ and $R$ denote $10 \mathrm{Dq}$ and the mean $M-\mathrm{O}$ distance for a standard specimen and $\Delta^{\prime}$ and $R^{\prime}$ denote those for an objective unknown specimen. Taking the mean $M-\mathrm{O}$ distance (Clark et al., 1969) and 10Dq value (White et al., 1971) of kosmochlor as a standard (Ikeda and Ohashi, 1974; Ikeda, 1984; Ikeda et al., 1992), the mean $M-\mathrm{O}$ distance obtained is $2.013 \AA$, which is consistent with the mean M3-O bond distance of the chromian epidotes (2.005 $\AA$ for CrEp1, 2.019 ̊ for CrEp2, and 2.013 $\AA$ for $\mathrm{CrEp} 3$ ) determined by the present $\mathrm{X}$-ray structural refinement.

All the bands of $\mathrm{Fe}^{3+}$ are assigned to spin-forbidden transitions, and thus, precise determination of the crystal field parameters of $\mathrm{Fe}^{3+}$ is difficult. However, the crystal field parameters of $\mathrm{Fe}^{3+}$ were calculated to be $10 \mathrm{Dq} \approx$ $12700 \mathrm{~cm}^{-1}$ and $\mathrm{B} \approx 670 \mathrm{~cm}^{-1}$, using a Tanabe-Sugano diagram. Although the other bands of $\mathrm{Fe}^{3+}$ are not distinct because of strong overlapping with those of $\mathrm{Cr}^{3+}$, the band positions of the ${ }^{4} \mathrm{~F}_{2 \mathrm{~g}}(\mathrm{G}) \leftarrow{ }^{6} \mathrm{~A}_{1 \mathrm{~g}}(\mathrm{~S})$ and ${ }^{4} \mathrm{~F}_{1 \mathrm{~g}}(\mathrm{G}) \leftarrow{ }^{6} \mathrm{~A}_{1 \mathrm{~g}}(\mathrm{~S})$ transitions are calculated to be $16100 \mathrm{~cm}^{-1}(620 \mathrm{~nm})$ and
$11400 \mathrm{~cm}^{-1}(880 \mathrm{~nm})$, respectively.

\section{Structural solution and refinements}

The number of measured and unique reflections with $R$ indices in the final least-squares calculations are given in Table 4. The unit cell parameters and crystallographic data are also shown in Table 4 . The refined atomic positions are listed in Table 5. The equivalent and anisotropic atomic displacement parameters are represented in Tables 5 and 6 , respectively. The interatomic distances calculated from the refined atomic positions are shown in Table 7.

After convergence of the structural refinements for the non-hydrogen atoms, a difference Fourier map was calculated in order to find the hydrogen atoms of the hydroxyl groups. Although the electron density distributions for CrEp1 and CrEp3 were not clear enough to detect hydrogen atoms, the difference Fourier maps of $\mathrm{CrEp} 2$ showed peak heights with $0.7 \mathrm{e}^{-3}$ at a position about $1 \AA$ from the $\mathrm{O} 10$ atom $(x=0.059, y=0.25$ and $z=0.359)$, which can be attributed to the hydrogen atom forming an $\mathrm{OH}$ group. Upon further refinement including the hydrogen atoms for $\mathrm{CrEp} 2$, where isotropic temperature factors were varied and the site occupancy of the hydrogen atom at the $\mathrm{H}$ position was fixed to 1.0 , the $R$ index and $S$-value

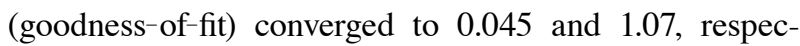
tively. The bond lengths of the $\mathrm{O} 10-\mathrm{H}$ and $\mathrm{O} 4 \cdots \mathrm{H}$ bonds were 0.65 and $2.29 \AA$, respectively.

The distribution of $\mathrm{Ca}$ and $\mathrm{Sr}$ at the $A 1$ and $A 2$ sites, 
Table 4. Crystallographic data of the chromian epidotes ${ }^{*}$ and experimental details of the single-crystal X-ray diffraction analysis

\begin{tabular}{|c|c|c|c|}
\hline Sample & CrEp $1^{* *}$ & $\operatorname{CrEp} 2^{* *}$ & $\mathrm{CrEp} 3^{* *}$ \\
\hline Space group & $P 2_{1} / m$ & $P 2_{1} / m$ & $P 2_{1} / m$ \\
\hline Crystal size (mm) & $0.20 \times 0.40 \times 0.20$ & $0.20 \times 0.20 \times 0.20$ & $0.50 \times 0.40 \times 0.10$ \\
\hline \multicolumn{4}{|l|}{ Cell parameters } \\
\hline$a(\AA)$ & $8.8815(6)$ & $8.9165(4)$ & $8.895(2)$ \\
\hline$b(\AA)$ & $5.5956(5)$ & $5.6226(2)$ & $5.610(1)$ \\
\hline$c(\AA)$ & $10.1532(5)$ & $10.1728(5)$ & $10.146(2)$ \\
\hline$\beta\left({ }^{\circ}\right)$ & $115.159(2)$ & $115.2365(9)$ & $115.177(2)$ \\
\hline$V\left(\AA^{3}\right)$ & $456.72(6)$ & $461.33(4)$ & $458.2(2)$ \\
\hline$D$ calc $\left(\mathrm{g} / \mathrm{cm}^{3}\right)$ & 3.474 & 3.459 & 3.486 \\
\hline Radiation & $\operatorname{Mo} K \alpha$ & $\operatorname{Mo} K \alpha$ & $\operatorname{Mo} K \alpha$ \\
\hline Monochrometer & Graphite & Graphite & Graphite \\
\hline Diffractometer & Rigaku RAXIS RAPID IP & Rigaku RAXIS RAPID IP & Bruker APEX CCD \\
\hline Scan type & $\omega$ scans & $\omega$ scans & $\phi$ and $\omega$ scans \\
\hline$\theta_{\min }\left({ }^{\circ}\right)$ & 2.22 & 2.21 & 2.22 \\
\hline$\theta_{\max }\left({ }^{\circ}\right)$ & 27.47 & 33.14 & 30.12 \\
\hline$\mu\left(\mathrm{mm}^{-1}\right)$ & 2.02 & 2.00 & 2.48 \\
\hline Collected reflections & 3930 & 9590 & 3405 \\
\hline Unique reflections & 1145 & 1853 & 1438 \\
\hline$R_{\text {int }}$ & 0.044 & 0.071 & 0.014 \\
\hline Miller index limits & $-11 \leq h \leq 10,-7 \leq k \leq 7,-12 \leq l \leq 13$ & $-13 \leq h \leq 13,-8 \leq k \leq 8,-15 \leq l \leq 15$ & $-12 \leq h \leq 10,-7 \leq k \leq 5,-13 \leq l \leq 14$ \\
\hline \multicolumn{2}{|c|}{ Refinement system used } & \multicolumn{2}{|c|}{ SHELXL-97 (Sheldrick, 1997) } \\
\hline Refinement on & $F^{2}$ & $F^{2}$ & $F^{2}$ \\
\hline$R 1$ (Unique reflections) & 0.0581 & 0.0661 & 0.032 \\
\hline$w R 2$ & 0.1542 & 0.0948 & 0.0912 \\
\hline$S$ & 1.275 & 1.087 & 1.329 \\
\hline No. of parameters & 124 & 123 & 124 \\
\hline \multirow[t]{3}{*}{ Weighting scheme } & $\omega=1 /\left[\sigma^{2}\left(F \mathrm{o}^{2}\right)+(0.0416 P)^{2}\right.$ & $\omega=1 /\left[\sigma^{2}\left(F \mathrm{o}^{2}\right)+(0.0321 P)^{2}\right.$ & $\omega=1 /\left[\sigma^{2}\left(F \mathrm{o}^{2}\right)+(0.0512 P)^{2}\right.$ \\
\hline & $+8.11 P]$ & $+1.46 P]$ & $+0.3144 P]$ \\
\hline & where $P=\left(F \mathrm{o}^{2}+2 F \mathrm{c}^{2}\right) / 3$ & where $P=\left(F \mathrm{o}^{2}+2 F \mathrm{c}^{2}\right) / 3$ & where $P=\left(F \mathrm{o}^{2}+2 F \mathrm{c}^{2}\right) / 3$ \\
\hline$(\Delta / \mathrm{s})_{\max }$ & 0.00 & 0.00 & 0.00 \\
\hline$\Delta r_{\max }\left(\mathrm{e} \AA^{-3}\right)$ & 1.350 & 0.903 & 2.020 \\
\hline$\Delta \mathrm{r}_{\min }\left(\mathrm{e} \AA^{-3}\right)$ & -0.899 & -0.795 & -1.200 \\
\hline
\end{tabular}

" Unit cell parameters were measured at $293 \mathrm{~K}$. Diffraction data were collected at $293 \mathrm{~K}$ for CrEp1 and CrEp2 and at $90 \mathrm{~K}$ for CrEp3.

** CrEpl: $\left(\mathrm{La}_{0.003} \mathrm{Pr}_{0.003} \mathrm{Nd}_{0.001} \mathrm{~K}_{0.004} \mathrm{Na}_{0.001} \mathrm{Ba}_{0.002} \mathrm{Sr}_{0.145} \mathrm{Ca}_{1.745} \mathrm{Mg}_{0.008} \mathrm{Mn}_{0.006}^{2+}\right)_{\Sigma 1.918}\left(\mathrm{Fe}_{0.487}^{3+} \mathrm{Cr}_{0.113}^{3+} \mathrm{Ti}_{0.008} \mathrm{Al}_{2.462}\right)_{\Sigma 3.070}\left(\mathrm{Al}_{0.048} \mathrm{Si}_{2.952}\right)_{\Sigma 3.000} \mathrm{O}_{13} \mathrm{H}_{0.992}$

CrEp2: $\left(\mathrm{La}_{0.002} \mathrm{Ce}_{0.001} \mathrm{Sm}_{0.002} \mathrm{Gd}_{0.001} \mathrm{~K}_{0.003} \mathrm{Na}_{0.006} \mathrm{Sr}_{0.083} \mathrm{Ca}_{1.869} \mathrm{Mg}_{0.010} \mathrm{Mn}_{0.006}^{2+}\right)_{\Sigma 1.983}\left(\mathrm{~V}_{0.003}^{3+} \mathrm{Fe}_{0.497}^{3+} \mathrm{Cr}_{0.315}^{3+} \mathrm{Ti}_{0.010} \mathrm{Al}_{2.212}\right)_{\Sigma 3.037^{-}}$

$\left(\mathrm{Al}_{0.068} \mathrm{Si}_{2.932}\right)_{\Sigma 3.000} \mathrm{O}_{13} \mathrm{H}_{0.984}$

CrEp3: $\left(\mathrm{La}_{0.002} \mathrm{Ce}_{0.004} \mathrm{Sm}_{0.001} \mathrm{Na}_{0.002} \mathrm{Sr}_{0.083} \mathrm{Ca}_{1.863} \mathrm{Mg}_{0.007} \mathrm{Mn}_{0.001}^{2+}\right)_{\Sigma 1.963}\left(\mathrm{Fe}_{0.531}^{3+} \mathrm{Cr}_{0.299}^{3+} \mathrm{Ti}_{0.005} \mathrm{Al}_{2.210}\right)_{\Sigma 3.035}\left(\mathrm{Al}_{0.045} \mathrm{Si}_{2.955}\right)_{\Sigma 3.000} \mathrm{O}_{13} \mathrm{H}_{0.844}$

where $\mathrm{H}$ was calculated based on the charge balance.

and the distribution of $\mathrm{Al}$ and $\mathrm{Cr}^{3+}$ at the $M 1, M 2$, and $M 3$ sites were determined based on the observed site-scattering values (Table 8) (Hawthorne et al., 1995). The sitescattering values were derived from the site occupancy of calcium ions at the $A 1$ and $A 2$ sites and of aluminum ions at the $M 1, M 2$, and $M 3$ sites, refined without any constraint. On the basis of the observed site-scattering values, the site populations (apfu) of the $A 1$ and $M 2$ sites in CrEp1, CrEp2, and CrEp3, and for the $M 1$ site in CrEp1, were fixed to be $1 \mathrm{Ca}, 1 \mathrm{Al}$, and $1 \mathrm{Al}$, respectively. The site populations of $\mathrm{Ca}$ and $\mathrm{Sr}$ on the $\mathrm{A} 2$ site, and of $\mathrm{Cr}$ and $\mathrm{Al}$ on the $M 1$ and $M 3$ sites were estimated by use of the following procedure: (1) trace elements not more than 0.01 apfu $(\mathrm{O}=12.5)$ were omitted, (2) $\mathrm{Fe}^{3+}$ was assigned to the $M 3$ site based on the result of the ${ }^{57} \mathrm{Fe}$ Mössbauer analy- sis, and (3) several reasonable constraints were applied as follows; $g(\mathrm{Ca})+g(\mathrm{Sr})=1$ for the $A 2$ site, $g(\mathrm{Al})+g(\mathrm{Cr})=$ 1 for the $M 1$ site, and $g(\mathrm{Al})+g(\mathrm{Cr})=1-g(\mathrm{Fe})$ for the $M 3$ site, where $g$ denotes the site population. The final site populations at the $A$ and $M$ sites are listed in Table 8 . The values of the $\mathrm{Sr}$ apfu at the $A 2$ sites $(0.14,0.10$, and 0.12 for CrEp1, CrEp2, and CrEp3, respectively) are similar to those given by the EPMA analysis ( 0.15 for CrEp1, 0.08 for $\mathrm{CrEp} 2$, and 0.08 for $\mathrm{CrEp} 3$ ). The $\mathrm{Cr}$ contents derived from the site-scattering values for CrEp1 (0.09 apfu) and CrEp2 (0.31 apfu) are consistent with those obtained from the EPMA analysis, whereas that of CrEp3 ( $0.22 \mathrm{apfu}$ ) is less than the EPMA data. The discrepancy of the $\mathrm{Cr}$ content in CrEp3 may be attributed to the inhomogeneous composition of CrEp3. Merli et al. (2000) showed that the 
Table 5. Atomic positions and equivalent displacement parameters $\left(\AA^{2}\right)$

\begin{tabular}{|c|c|c|c|c|c|c|c|c|c|c|c|c|c|}
\hline Atom & $n_{\mathrm{eq}}{ }^{*}$ & $\mathrm{~W}^{* *}$ & $\begin{array}{l}x, y, z, \\
U_{\mathrm{eq}}\end{array}$ & CrEp 1 & CrEp 2 & CrEp 3 & Atom & $n_{\mathrm{eq}}{ }^{*}$ & $\mathrm{~W}^{* *}$ & $\begin{array}{l}x, y, z \\
U_{\mathrm{eq}}\end{array}$ & CrEp 1 & CrEp 2 & CrEp 3 \\
\hline \multirow[t]{4}{*}{$A 1$} & 2 & $e$ & $x$ & $0.7608(2)$ & $0.7600(1)$ & $0.76037(7)$ & $\mathrm{O} 2$ & 4 & $f$ & $x$ & $0.3008(6)$ & $0.3017(3)$ & $0.3015(2)$ \\
\hline & & & $y$ & $3 / 4$ & $3 / 4$ & $3 / 4$ & & & & $y$ & $0.9834(9)$ & $0.9838(4)$ & $0.9838(3)$ \\
\hline & & & $z$ & $0.1547(2)$ & $0.15390(9)$ & $0.15416(6)$ & & & & $z$ & $0.3513(5)$ & $0.3527(2)$ & $0.3524(2)$ \\
\hline & & & $U_{\text {eq }}$ & $0.0115(7)$ & $0.0131(3)$ & $0.0065(2)$ & & & & $U_{\text {eq }}$ & $0.011(1)$ & $0.0122(4)$ & $0.0074(3)$ \\
\hline \multirow[t]{4}{*}{$A 2$} & 2 & $e$ & $x$ & $0.6033(2)$ & $0.6040(1)$ & $0.60519(7)$ & $\mathrm{O} 3$ & 4 & $f$ & $x$ & $0.7914(6)$ & $0.7926(3)$ & $0.7926(2)$ \\
\hline & & & $y$ & $3 / 4$ & $3 / 4$ & $3 / 4$ & & & & $y$ & $0.0135(9)$ & $0.0135(4)$ & $0.0127(3)$ \\
\hline & & & $z$ & $0.4231(2)$ & $0.42367(9)$ & $0.42459(5)$ & & & & $z$ & $0.3437(5)$ & $0.3425(2)$ & $0.3430(2)$ \\
\hline & & & $U_{\text {eq }}$ & $0.0135(6)$ & $0.0149(2)$ & $0.0074(2)$ & & & & $U_{\text {eq }}$ & $0.012(1)$ & $0.0129(4)$ & $0.0079(3)$ \\
\hline \multirow[t]{4}{*}{$M 1$} & 2 & $a$ & $x$ & 0 & 0 & 0 & $\mathrm{O} 4$ & 2 & $e$ & $x$ & $0.0531(8)$ & $0.0533(4)$ & $0.0523(3)$ \\
\hline & & & $y$ & 0 & 0 & 0 & & & & $y$ & $1 / 4$ & $1 / 4$ & $1 / 4$ \\
\hline & & & $z$ & 0 & 0 & 0 & & & & $z$ & $0.1312(7)$ & $0.1313(3)$ & $0.1315(2)$ \\
\hline & & & $U_{\text {eq }}$ & $0.0044(9)$ & $0.0085(3)$ & $0.0041(3)$ & & & & $U_{\text {eq }}$ & $0.011(1)$ & $0.0110(6)$ & $0.0066(4)$ \\
\hline \multirow[t]{4}{*}{$M 2$} & 2 & $c$ & $x$ & 0 & 0 & 0 & O5 & 2 & $e$ & $x$ & $0.0395(8)$ & $0.0403(3)$ & $0.0394(3)$ \\
\hline & & & $y$ & 0 & 0 & 0 & & & & $y$ & $3 / 4$ & $3 / 4$ & $3 / 4$ \\
\hline & & & $z$ & $1 / 2$ & $1 / 2$ & $1 / 2$ & & & & $z$ & $0.1441(7)$ & $0.1456(3)$ & $0.1445(2)$ \\
\hline & & & $U_{\text {eq }}$ & $0.0051(9)$ & $0.0082(4)$ & $0.0039(3)$ & & & & $U_{\text {eq }}$ & $0.008(1)$ & $0.0090(5)$ & $0.0063(4)$ \\
\hline \multirow[t]{4}{*}{ M3 } & 2 & $e$ & $x$ & $0.2904(2)$ & $0.29148(9)$ & $0.29116(7)$ & O6 & 2 & $e$ & $x$ & $0.0629(8)$ & $0.0647(4)$ & $0.0640(3)$ \\
\hline & & & $y$ & $1 / 4$ & $1 / 4$ & $1 / 4$ & & & & $y$ & $3 / 4$ & $3 / 4$ & $3 / 4$ \\
\hline & & & $z$ & $0.2225(2)$ & $0.22236(9)$ & $0.22201(6)$ & & & & $z$ & $0.4034(7)$ & $0.4046(3)$ & $0.4043(2)$ \\
\hline & & & $U_{\text {eq }}$ & $0.0101(7)$ & $0.0095(2)$ & $0.0047(2)$ & & & & $U_{\text {eq }}$ & $0.010(1)$ & $0.0109(6)$ & $0.0064(4)$ \\
\hline \multirow[t]{4}{*}{ Sil } & 2 & $e$ & $x$ & $0.3385(3)$ & $0.3397(1)$ & $0.3399(1)$ & O7 & 2 & $e$ & $x$ & $0.5162(8)$ & $0.5157(4)$ & $0.5165(3)$ \\
\hline & & & $y$ & $3 / 4$ & $3 / 4$ & $3 / 4$ & & & & $y$ & $3 / 4$ & $3 / 4$ & $3 / 4$ \\
\hline & & & $z$ & $0.0470(3)$ & $0.0477(1)$ & $0.04806(9)$ & & & & $z$ & $0.1773(7)$ & $0.1784(3)$ & $0.1785(2)$ \\
\hline & & & $U_{\text {eq }}$ & $0.0080(6)$ & $0.0096(2)$ & $0.0049(2)$ & & & & $U_{\text {eq }}$ & $0.012(1)$ & $0.0138(6)$ & $0.0081(4)$ \\
\hline \multirow[t]{4}{*}{$\mathrm{Si} 2$} & 2 & $e$ & $x$ & $0.6820(3)$ & $0.6830(1)$ & $0.6827(1)$ & O8 & 2 & $e$ & $x$ & $0.5177(9)$ & $0.5206(4)$ & $0.5202(3)$ \\
\hline & & & $y$ & $1 / 4$ & $1 / 4$ & $1 / 4$ & & & & $y$ & $1 / 4$ & $1 / 4$ & $1 / 4$ \\
\hline & & & $z$ & $0.2759(3)$ & $0.2758(1)$ & $0.27594(8)$ & & & & $z$ & $0.3032(8)$ & $0.3051(4)$ & $0.3054(3)$ \\
\hline & & & $U_{\mathrm{eq}}$ & $0.0098(6)$ & $0.0096(2)$ & $0.0055(2)$ & & & & $U_{\text {eq }}$ & $0.017(1)$ & $0.0177(7)$ & $0.0112(4)$ \\
\hline \multirow[t]{4}{*}{$\mathrm{Si} 3$} & 2 & $e$ & $x$ & $0.1820(3)$ & $0.1828(1)$ & $0.1827(1)$ & O9 & 2 & $e$ & $x$ & $0.6359(9)$ & $0.6340(4)$ & $0.6346(3)$ \\
\hline & & & $y$ & $3 / 4$ & $3 / 4$ & $3 / 4$ & & & & $y$ & $1 / 4$ & $1 / 4$ & $1 / 4$ \\
\hline & & & $z$ & $0.3161(3)$ & $0.3169(1)$ & $0.31692(9)$ & & & & $z$ & $0.1018(8)$ & $0.1016(4)$ & $0.1018(2)$ \\
\hline & & & $U_{\mathrm{eq}}$ & $0.0083(6)$ & $0.0091(2)$ & $0.0051(2)$ & & & & $U_{\text {eq }}$ & $0.020(2)$ & $0.0214(7)$ & $0.0128(5)$ \\
\hline \multirow[t]{4}{*}{$\mathrm{O} 1$} & 4 & $f$ & $x$ & $0.2356(5)$ & $0.2354(2)$ & $0.2353(2)$ & $\mathrm{O} 10$ & 2 & $e$ & $x$ & $0.0777(8)$ & $0.0798(4)$ & $0.0789(3)$ \\
\hline & & & $y$ & $0.9955(9)$ & $0.9954(4)$ & $0.9961(3)$ & & & & $y$ & $1 / 4$ & $1 / 4$ & $1 / 4$ \\
\hline & & & $z$ & $0.0444(5)$ & $0.0436(2)$ & $0.0441(2)$ & & & & $z$ & $0.4257(7)$ & $0.4261(3)$ & $0.4255(2)$ \\
\hline & & & $U_{\text {eq }}$ & $0.012(1)$ & $0.0120(4)$ & $0.0069(3)$ & & & & $U_{\mathrm{eq}}$ & $0.009(1)$ & $0.0110(6)$ & $0.0063(4)$ \\
\hline
\end{tabular}

${ }^{*}$ Multiplicity.

${ }^{* *}$ Wyckoff letter.

estimates of the site-scattering values from X-ray diffraction data are often different from those obtained from EPMA analysis on inhomogeneous (zoned) crystals.

To examine the feasibility of the structural models, the bond-valence sums in CrEp1, CrEp2, and CrEp3 were calculated using the function of the electrostatic strength by Brown and Altermatt (1985) and the bond-valence parameters of Brese and O'Keeffe (1991) (Table 9). The valence sums of the A1, M1, M2, Si1, Si2, O3, O5, O6, O7, $\mathrm{O} 8$, and $\mathrm{O} 9$ are close to their expected valence sums, whereas those of the $A 2, \mathrm{O} 1, \mathrm{O} 2, \mathrm{O} 4, \mathrm{O} 8$, and $\mathrm{O} 10$ are less than their expected values. Since hydrogen atoms 
Table 6. Anisotropic displacement parameters $\left(\AA^{2}\right)$

\begin{tabular}{|c|c|c|c|c|c|c|c|c|c|}
\hline Atom & $U i j$ & CrEp 1 & CrEp 2 & CrEp 3 & Atom & $U_{i j}$ & CrEp 1 & CrEp 2 & CrEp 3 \\
\hline \multirow[t]{6}{*}{$A 1$} & $U 11$ & $0.014(1)$ & $0.0163(4)$ & $0.0087(3)$ & $\mathrm{O} 2$ & $U 11$ & $0.012(2)$ & $0.0127(9)$ & $0.0082(7)$ \\
\hline & $U 22$ & $0.011(1)$ & $0.0138(5)$ & $0.0072(3)$ & & $U 22$ & $0.010(2)$ & $0.012(1)$ & $0.0082(7)$ \\
\hline & $U 33$ & $0.012(1)$ & $0.0119(4)$ & $0.0050(3)$ & & $U 33$ & $0.011(2)$ & $0.0121(9)$ & $0.0061(6)$ \\
\hline & $U 23$ & 0 & 0 & 0 & & $U 23$ & $-0.001(2)$ & $-0.0007(8)$ & $-0.0011(5)$ \\
\hline & $U 13$ & $0.0085(8)$ & $0.0085(3)$ & $0.0041(2)$ & & $U 13$ & $0.005(2)$ & $0.0056(8)$ & $0.0034(5)$ \\
\hline & $U 12$ & 0 & 0 & 0 & & $U 12$ & $-0.003(2)$ & $-0.0024(8)$ & $-0.0019(5)$ \\
\hline \multirow[t]{6}{*}{$A 2$} & $U 11$ & $0.0152(9)$ & $0.0153(4)$ & $0.0090(3)$ & $\mathrm{O} 3$ & $U 11$ & $0.010(2)$ & $0.0123(9)$ & $0.0076(7)$ \\
\hline & $U 22$ & $0.015(1)$ & $0.0194(5)$ & $0.0095(3)$ & & $U 22$ & $0.010(2)$ & $0.010(1)$ & $0.0056(7)$ \\
\hline & $U 33$ & $0.0102(9)$ & $0.0098(4)$ & $0.0037(3)$ & & $U 33$ & $0.013(2)$ & $0.0130(9)$ & $0.0075(7)$ \\
\hline & $U 23$ & 0 & 0 & 0 & & $U 23$ & $-0.001(2)$ & $-0.0001(8)$ & $-0.0003(5)$ \\
\hline & $U 13$ & $0.0054(7)$ & $0.0051(3)$ & $0.0027(2)$ & & $U 13$ & $0.000(2)$ & $0.0022(8)$ & $0.0003(5)$ \\
\hline & $U 12$ & 0 & 0 & 0 & & $U 12$ & $0.001(2)$ & $0.0004(8)$ & $0.0002(5)$ \\
\hline \multirow[t]{6}{*}{$M 1$} & $U 11$ & $0.003(1)$ & $0.0089(5)$ & $0.0051(4)$ & $\mathrm{O} 4$ & $U 11$ & $0.011(3)$ & $0.014(1)$ & $0.0074(9)$ \\
\hline & $U 22$ & $0.003(1)$ & $0.0095(6)$ & $0.0045(4)$ & & $U 22$ & $0.008(3)$ & $12(1)$ & $0.0076(9)$ \\
\hline & $U 33$ & $0.006(1)$ & 0.007 & 0.00 & & $U 33$ & & & \\
\hline & $U 23$ & $-0.001(1)$ & $-0.001(4)$ & $-0.0003(3)$ & & $U 23$ & 0 & 0 & 0 \\
\hline & $U 13$ & $0.001(1)$ & $0.0035(4)$ & $0.0018(3)$ & & $U 13$ & $0.005(3)$ & $97(1)$ & $0.0031(7)$ \\
\hline & $U 12$ & $-0.001(1)$ & $-0.0004(4)$ & $-0.0004(3)$ & & $U 12$ & 0 & 0 & 0 \\
\hline \multirow[t]{6}{*}{$M 2$} & $U 11$ & 0.00 & 0.00 & 0.0 & O5 & $U 11$ & & & \\
\hline & $U 22$ & $0.003(1)$ & $0.0070(6)$ & 0.00 & & $U 22$ & $5(3)$ & & 670(9) \\
\hline & $U 33$ & $0.007(1)$ & $0.0091(6)$ & 0.003 & & $U 33$ & & & $49(9)$ \\
\hline & $U 23$ & $0.001(1)$ & $0.0000(4)$ & $0.0000(3)$ & & $U 23$ & 0 & 0 & 0 \\
\hline & $U 13$ & $0.001(1)$ & 0.00 & 0.0 & & $U 13$ & & & \\
\hline & $U 12$ & 0.000 & 0.00 & 0.0 & & $U 12$ & 0 & 0 & 0 \\
\hline \multirow[t]{6}{*}{$M 3$} & $U 11$ & $0.010(1)$ & $0.0083(4)$ & 0.00 & O6 & $U 11$ & $13(3)$ & $3(1)$ & $84(9)$ \\
\hline & $U 22$ & $0.008(1)$ & $0.0108(4)$ & 0.00 & & $U 22$ & $0.008(3)$ & & $058(9)$ \\
\hline & $U 33$ & $0.013(1)$ & $0.0092(4)$ & $0.0038(3)$ & & $U 33$ & & & $0.0071(9)$ \\
\hline & $U 23$ & 0 & 0 & 0 & & $U 23$ & 0 & 0 & 0 \\
\hline & $U 13$ & 0.0051 & 0.00 & 0.00 & & $U 13$ & & & 0.0 \\
\hline & $U 12$ & 0 & 0 & 0 & & $U 12$ & 0 & 0 & 0 \\
\hline \multirow[t]{6}{*}{ Sil } & $U 11$ & $0.009(1)$ & $0.0095(5)$ & 0.00 & O7 & $U 11$ & $0.008(3)$ & & $0.0072(9)$ \\
\hline & $U 22$ & & & & & $U 22$ & & & \\
\hline & $U 33$ & 0.009 & 0.008 & 0.00 & & $U 33$ & 0.0 & & $6(9)$ \\
\hline & $U 23$ & 0 & 0 & 0 & & $U 23$ & 0 & 0 & 0 \\
\hline & $U 13$ & $0.005(1)$ & $0.0043(4)$ & $0.0020(3)$ & & $U 13$ & & & $0.0010(8)$ \\
\hline & $U 12$ & 0 & 0 & 0 & & $U 12$ & 0 & 0 & 0 \\
\hline \multirow[t]{6}{*}{ Si2 } & $U 11$ & & & & O8 & $U 11$ & & & \\
\hline & $U 22$ & .007 & 0.00 & 0.00 & & $U 22$ & $0.017(4)$ & $7(2)$ & $0.011(1)$ \\
\hline & $U 33$ & $0.011(1)$ & $0.0085(5)$ & $0.0043(4)$ & & U33 & $0.020(4)$ & & $0.015(1)$ \\
\hline & $U 23$ & 0 & 0 & 0 & & $U 23$ & 0 & 0 & 0 \\
\hline & $U 13$ & & & & & & & & \\
\hline & $U 12$ & 0 & 0 & 0 & & $U 12$ & 0 & 0 & 0 \\
\hline \multirow[t]{6}{*}{$\mathrm{Si} 3$} & $U 11$ & & & 0.00 & O9 & $U 11$ & & & $8(1)$ \\
\hline & $U 22$ & $0.008(1)$ & $0.0101(6)$ & $0.0061(4)$ & & $U 22$ & $0.025(4)$ & $0.030(2)$ & $0.016(1)$ \\
\hline & $U 33$ & & & & & $U 33$ & & & \\
\hline & $U 23$ & 0 & 0 & 0 & & $U 23$ & 0 & 0 & 0 \\
\hline & $U 13$ & $0.004(1)$ & $0.0043(4)$ & $0.0023(3)$ & & $U 13$ & 0.00 & 0.0 & $0.0070(9)$ \\
\hline & $U 12$ & 0 & 0 & 0 & & $U 12$ & 0 & 0 & 0 \\
\hline \multirow[t]{6}{*}{01} & $U 11$ & $0.010(2)$ & $0.0120(9)$ & $0.0074(6)$ & O10 & $U 11$ & $0.014(3)$ & $0.013(1)$ & $0.0079(9)$ \\
\hline & $U 22$ & & & & & $U 22$ & & & \\
\hline & $U 33$ & & & & & $U 33$ & $0.009(3)$ & & $0.0052(9)$ \\
\hline & $U 23$ & & & 0.00 & & $U 23$ & 0 & 0 & 0 \\
\hline & $U 13$ & $0.004(2)$ & $0.0063(8)$ & $0.0029(5)$ & & $U 13$ & $0.009(3)$ & $0.008(1)$ & $0.0038(8)$ \\
\hline & $U 12$ & $0.001(2)$ & $0.0004(8)$ & $0.0008(5)$ & & $U 12$ & 0 & 0 & 0 \\
\hline
\end{tabular}


Table 7. Interatomic distances $(\AA)$

\begin{tabular}{|c|c|c|c|c|}
\hline & & CrEp 1 & CrEp 2 & CrEp 3 \\
\hline$A 1-\mathrm{O} 1$ & $\times 2$ & $2.484(5)$ & $2.482(2)$ & $2.479(2)$ \\
\hline$-\mathrm{O} 3$ & $\times 2$ & $2.342(5)$ & $2.342(2)$ & $2.336(2)$ \\
\hline$-\mathrm{O} 5$ & & $2.524(7)$ & $2.537(3)$ & $2.525(2)$ \\
\hline-06 & & $2.796(7)$ & $2.825(3)$ & $2.811(2)$ \\
\hline-07 & & $2.278(7)$ & $2.295(3)$ & $2.285(2)$ \\
\hline Average & & 2.464 & 2.472 & 2.464 \\
\hline-09 & $\times 2$ & $2.973(3)$ & $2.990(1)$ & $2.983(1)$ \\
\hline Average & & 2.577 & 2.587 & 2.580 \\
\hline$A 2-\mathrm{O} 2$ & $\times 2$ & $2.791(5)$ & $2.803(2)$ & $2.806(2)$ \\
\hline$-\mathrm{O} 2^{\prime}$ & $\times 2$ & $2.557(5)$ & $2.548(2)$ & $2.538(2)$ \\
\hline$-\mathrm{O} 3$ & $\times 2$ & $2.600(5)$ & $2.624(2)$ & $2.610(2)$ \\
\hline-07 & & $2.277(7)$ & $2.274(3)$ & $2.276(2)$ \\
\hline-010 & & $2.586(7)$ & $2.571(3)$ & $2.564(2)$ \\
\hline Average & & 2.595 & 2.599 & 2.594 \\
\hline-08 & $\times 2$ & $3.017(3)$ & $3.024(1)$ & $3.021(1)$ \\
\hline Average & & 2.679 & 2.684 & 2.679 \\
\hline Sil -O1 & $\times 2$ & $1.644(5)$ & $1.654(2)$ & $1.656(2)$ \\
\hline-07 & & $1.571(7)$ & $1.566(3)$ & $1.566(2)$ \\
\hline-09 & & $1.621(8)$ & $1.633(3)$ & $1.631(2)$ \\
\hline Average & & 1.620 & 1.627 & 1.627 \\
\hline $\mathrm{Si} 2-\mathrm{O} 3$ & $\times 2$ & $1.612(5)$ & $1.618(2)$ & $1.621(2)$ \\
\hline-08 & & $1.598(7)$ & $1.598(3)$ & $1.596(2)$ \\
\hline-09 & & $1.635(8)$ & $1.634(3)$ & $1.631(2)$ \\
\hline Average & & 1.614 & 1.617 & 1.617 \\
\hline $\mathrm{Si} 3-\mathrm{O} 2$ & $\times 2$ & $1.621(5)$ & $1.630(2)$ & $1.626(2)$ \\
\hline-05 & & $1.665(7)$ & $1.662(3)$ & $1.670(2)$ \\
\hline-06 & & $1.643(7)$ & $1.646(3)$ & $1.642(2)$ \\
\hline Average & & 1.638 & 1.642 & 1.641 \\
\hline$M 1-\mathrm{O} 1$ & $\times 2$ & $1.944(4)$ & $1.952(2)$ & $1.945(2)$ \\
\hline$-\mathrm{O} 4$ & $\times 2$ & $1.849(4)$ & $1.856(2)$ & $1.853(1)$ \\
\hline$-\mathrm{O} 5$ & $\times 2$ & $1.945(4)$ & $1.961(2)$ & $1.950(1)$ \\
\hline Average & & 1.913 & 1.923 & 1.916 \\
\hline$M 2-\mathrm{O} 3$ & $\times 2$ & $1.860(4)$ & $1.862(2)$ & $1.856(2)$ \\
\hline-06 & $\times 2$ & $1.923(5)$ & $1.931(2)$ & $1.925(2)$ \\
\hline-010 & $\times 2$ & $1.856(4)$ & $1.872(2)$ & $1.866(1)$ \\
\hline Average & & 1.880 & 1.888 & 1.882 \\
\hline M3-O1 & $\times 2$ & $2.188(5)$ & $2.198(2)$ & $2.184(2)$ \\
\hline$-\mathrm{O} 2$ & $\times 2$ & $1.960(5)$ & $1.975(2)$ & $1.971(2)$ \\
\hline$-\mathrm{O} 4$ & & $1.908(7)$ & $1.921(3)$ & $1.923(2)$ \\
\hline-08 & & $1.828(7)$ & $1.848(3)$ & $1.844(2)$ \\
\hline Average & & 2.005 & 2.019 & 2.013 \\
\hline
\end{tabular}

forming the $\mathrm{H}-\mathrm{O} 10$ and $\mathrm{H} \cdots \mathrm{O} 4$ bonds were observed in CrEp2, the low bond-valence sums for the O4 (1.73 v.u.) and $\mathrm{O} 10$ (1.30 v.u.) in this study may be compensated by the bond valences between the hydrogen and oxygen atoms. Similar results have also been reported for allanite (Hoshino et al., 2005) and dissakisite-(La) (Lavina et al., 2006). On the other hand, the reason for smaller valence sums of the $\mathrm{O} 1, \mathrm{O} 2$, and $\mathrm{O} 8$ is not obvious. Hoshino et al. (2005) interpreted the reason of the low $\mathrm{O} 2$ and $\mathrm{O} 8$ bond valences in terms of the effect of defect at the $A 2$ site. However, there is no strong evidence suggesting defects at the $A 2$ site in the present chromian epidotes. On the basis of the fact that the $\mathrm{O} 1, \mathrm{O} 2$, and $\mathrm{O} 8$ oxygen atoms belong to the strongly distorted $M 3$ site, and the effect of the distortion of coordination polyhedra on the bond-strength to bond-length relationship (Brown and Shannon, 1973), the relatively low bond valences of the $\mathrm{O} 1, \mathrm{O} 2$, and $\mathrm{O} 8$ oxygen atoms are suggested to be caused by the distortion of the $M 3$ octahedra.

\section{DISCUSSION}

\section{Cr distribution in the octahedral sites}

In epidote group minerals, the $M 3$ site is essentially larger and more distorted than the $M 1$ and $M 2$ sites (Ito et al., 1954; Dollase, 1968). This feature controls the distribution of transition elements in the three independent octahedral sites. Thus, the stronger preferences of $\mathrm{Fe}^{3+}$ and $\mathrm{Mn}^{3+}$ than $\mathrm{Al}^{3+}$ for the $M 3$ site are reasonable in both natural and synthetic epidotes (Dollase, 1971; Giuli et al., 1999; others) and piemontites (Dollase, 1969; Langer et al., 2002; Nagashima and Akasaka, 2004; others), although it is also noted that $\mathrm{Fe}^{3+}$ and $\mathrm{Mn}^{3+}$ ions tend to occupy the $M 1$ site, even when the $M 3$ site is not fully occupied by $\mathrm{Fe}^{3+}$ and $\mathrm{Mn}^{3+}$ (Giuli et al., 1999; Langer et al., 2002; Nagashima and Akasaka, 2004). In addition to the geometric properties of the $M$ sites, REE cations in the $A 2$ site also affect the distribution of cations among the $M$ sites. In allanite, larger divalent cations, such as $\mathrm{Fe}^{2+}$ occupy the $M 3$ site, and smaller $\mathrm{Fe}^{3+}$ ions distribute in the $M 1$ sites, which can be explained in terms of the substitution of $\left[\mathrm{Ca}^{2+}\right]^{A 2}+\left[\mathrm{Al}^{3+}\right]^{M 3} \leftrightarrow\left[\mathrm{REE}^{3+}\right]^{A 2}+\left[\mathrm{M}^{2+}\right]^{M 3}$ (Dollase, 1971). On the basis of similar considerations, $\mathrm{Mg}^{2+}$ and $\mathrm{Cr}^{3+}$ in chromian dissakisite-(Ce) were assigned to the $M 3$ and $M 1$ sites, respectively (Yang and Enami, 2003). For the Outokumpu chromian epidote, in which $33 \%$ of the octahedral sites were filled with $\mathrm{Cr}^{3+}$ ions, Treloar (1987) predicted that $\mathrm{Cr}^{3+}$ might be preferentially partitioned into one of the three octahedral sites, probably the $M 1$ site. This interpretation was partly based on the results of a polarized absorption spectroscopic study by Burns and Strens (1967) which showed that $\mathrm{Cr}^{3+}$ had a strong preference for the $M 1$ site. In terms of the assignment of the crystal field spectra, Liebscher (2004) expressed doubts about the distribution of $\mathrm{Cr}^{3+}$ at the $M 1$ site. If the amounts of $\mathrm{Fe}^{3+}$ and/or $\mathrm{Mn}^{3+}$ are sufficient to fill the $M 3$ site in chromian epidotes, then $\mathrm{Cr}^{3+}$ ions would be partitioned on the $M 1$ site, because the ionic radius of $\mathrm{Cr}^{3+}(0.62 \AA$ after Shannon (1976)) is smaller than those of both $\mathrm{Mn}^{3+}(0.65 \AA)$ and $\mathrm{Fe}^{3+}(0.645 \AA)$. However, $\mathrm{Cr}^{3+}$ 
Table 8. Refined site-scattering values* and assigned site-populations** for the A1, A2, M1, M2 and M3 sites

\begin{tabular}{lllll}
\hline Sample & Site & Site scattering & Site populations (apfu) & Number of electrons \\
\hline CrEp1 & $M 1$ & $12.94(20)$ & $1 \mathrm{Al}$ & 13 \\
& $M 2$ & $12.44(20)$ & $1 \mathrm{Al}$ & 13 \\
& $M 3$ & $20.14(23)$ & $0.43 \mathrm{Al}+0.09 \mathrm{Cr}^{3+}+0.48 \mathrm{Fe}^{3+}$ & 20.23 \\
& $A 2$ & $22.72(24)$ & $0.86 \mathrm{Ca}+0.14 \mathrm{Sr}$ & 22.52 \\
& $A 1$ & $19.66(24)$ & $1 \mathrm{Ca}$ & 20 \\
CrEp2 & $M 1$ & $14.50(9)$ & $0.86 \mathrm{Al}+0.14 \mathrm{Cr}^{3+}$ & 14.54 \\
& $M 2$ & $13.12(9)$ & $1 \mathrm{Al}$ & 13 \\
& $M 3$ & $21.28(9)$ & $0.34 \mathrm{Al}+0.17 \mathrm{Cr}^{3+}+0.49 \mathrm{Fe}^{3+}$ & 21.24 \\
& $A 2$ & $21.86(10)$ & $0.90 \mathrm{Ca}+0.10 \mathrm{Sr}$ & 21.80 \\
& $A 1$ & $19.78(10)$ & $1 \mathrm{Ca}$ & 20 \\
CrEp3 & $M 1$ & $14.09(7)$ & $0.90 \mathrm{Al}+0.10 \mathrm{Cr}^{3+}$ & 14.10 \\
& $M 2$ & $12.75(7)$ & $1 \mathrm{Al}$ & 20.95 \\
& $M 3$ & $20.93(7)$ & $0.37 \mathrm{Al}+0.12 \mathrm{Cr}^{3+}+0.51 \mathrm{Fe}^{3+}$ & 22.16 \\
& $A 2$ & $22.16(6)$ & $0.88 \mathrm{Ca}+0.12 \mathrm{Sr}^{3+}$ & 20 \\
\hline
\end{tabular}

* The site-scattering values were derived from the site occupancies of calcium at the $A 1$ and $A 2$ sites and aluminum at the $M 1, M 2$ and $M 3$ sites refined without any constraint.

** Cations not more than $0.01 \mathrm{apfu}$ were neglected. $\mathrm{Fe}^{3+}$ was assigned to the $M 3$ site by the Mössbauer analysis. The amounts of $\mathrm{Fe}^{3+}$ were recalculated from the EPMA data by normalizing total cations at the octahedral sites to the ideal value, 3 apfu.

*** Calculated from the site populations.

is considered to occupy the $M 3$ site in epidote in which the amounts of $\mathrm{Fe}^{3+}$ and/or $\mathrm{Mn}^{3+}$ ions on the $M 3$ site and of REE ions on the $A 2$ site are insignificant.

The result in this study gives a solution to the questions on the distribution of $\mathrm{Cr}^{3+}$ among the octahedral sites in the epidote structure. As shown in Table 8, the $\mathrm{Cr}^{3+}+\mathrm{Fe}^{3+}$ population at the $M 3$ site and the $\mathrm{Cr}^{3+}$ population at the $M 1$ site are related to the $\mathrm{Cr}^{3+}+\mathrm{Fe}^{3+}$ content in the epidote, i.e., a certain amount of $\mathrm{Cr}^{3+}$ is distributed at the $M 1$ site in the samples with the $\mathrm{Cr}^{3+}+\mathrm{Fe}^{3+}$ exceeding 0.6 apfu. It is also evident that $\mathrm{Cr}^{3+}$ ions are distributed at the $M 1$ site even if the $M 3$ site is not fully occupied by $\mathrm{Cr}^{3+}+\mathrm{Fe}^{3+}$. In addition, the behavior of $\mathrm{Cr}^{3+}$ and $\mathrm{Fe}^{3+}$ is different from each other: $\mathrm{Fe}^{3+}$ ions exclusively distribute at the $M 3$ site, whereas $\mathrm{Cr}^{3+}$ ions distribute at both the $M 3$ and $M 1$ sites with $\mathrm{Cr}^{3+}(M 1): \mathrm{Cr}^{3+}(M 3)$ ratios of 0:0.07, 0.136:0.153, and 0.100:0.101 for CrEp1, CrEp2, and $\mathrm{CrEp} 3$, respectively. The exclusive distribution of $\mathrm{Fe}^{3+}$ at the $M 3$ site in the chromian epidotes is reasonable, because if the total $\mathrm{Fe}^{3+}$ content is less than 0.5 apfu, $\mathrm{Fe}^{3+}$ cations occupy the M3 site (Dollase, 1971; Guili et al., 1999). Although the site populations of $\mathrm{Cr}^{3+}$ at the $M 1$ and $M 3$ sites are nearly even in CrEp2 and CrEp3, the distribution coefficient $\left(K_{\mathrm{D}}=\left(\mathrm{Cr}^{3+} / \mathrm{Al}\right)^{M 1} /\left(\mathrm{Cr}^{3+} / \mathrm{Al}\right)^{M 3}\right)$ representing the relationship between $\mathrm{Cr}^{3+}$ and $\mathrm{Al}$ populations at the $M 1$ and $M 3$ sites are 0.35(3) for CrEp2 and 0.41(3) for $\mathrm{CrEp} 3$. The selective distribution of $\mathrm{Cr}^{3+}$ at the $M 3$ site in CrEp1 and the $K_{\mathrm{D}}$ values of CrEp2 and CrEp3 indicate a stronger preference of $\mathrm{Cr}^{3+}$ for the $M 3$ site than that of
$\mathrm{Al}^{3+}$. Thus, in the case of the distributions of $\mathrm{Cr}^{3+}$ and $\mathrm{Al}^{3+}$ in epidote, the preference of $\mathrm{Cr}^{3+}$ at the $M$ sites is $M 3$ > $M 1 \gg M 2$. On the other hand, the preferences of $\mathrm{Fe}^{3+}$, $\mathrm{Cr}^{3+}$, and $\mathrm{Al}^{3+}$ for the $M 1$ and $M 3$ sites are $\mathrm{Al}^{3+}>\mathrm{Cr}^{3+}>$ $\mathrm{Fe}^{3+}$ for the $M 1$ site and $\mathrm{Fe}^{3+}>\mathrm{Cr}^{3+}>\mathrm{Al}^{3+}$ for the $M 3$ site.

\section{Relationship between $\mathrm{Cr}$ distribution in the octahe- dral sites and structural changes}

In the chromian epidotes, the unit-cell parameters of $a, b$, and $c$ and the cell volume increase with increasing $\mathrm{Cr}^{3+}$ content in epidote, which would be caused by the expansion of the $M 3 \mathrm{O}_{6}$ and $M 1 \mathrm{O}_{6}$ octahedra due to the ionic substitutions of the larger $\mathrm{Cr}^{3+}$ and $\mathrm{Fe}^{3+}$ for the smaller $\mathrm{Al}^{3+}$.

The expansion of the $M 1$ and $M 3$ octahedra by the substitutions of $\mathrm{Cr}^{3+}$ for $\mathrm{Al}^{3+}$ at the $M 1$ site and of $\mathrm{Cr}^{3+}+$ $\mathrm{Fe}^{3+}$ for $\mathrm{Al}$ at the $M 3$ site, respectively, is confirmed by the relationship between the mean $M$-O distance, $<M^{-}$ $\mathrm{O}>$, and the mean ionic radius, $r(\AA)$, (Figs. 3 and 4) represented as follows;

$$
<M 1-\mathrm{O}>=1.343 r+1.186\left(R^{2}=0.75\right)
$$

and

$$
<M 3-\mathrm{O}>=0.586 r+1.659\left(R^{2}=0.93\right)
$$

The gradients of Equations (1) and (2) are close to those of the synthetic $\mathrm{Ca}_{2}\left(\mathrm{Al}_{1} \mathrm{Fe}^{3+}\right)_{3} \mathrm{Si}_{3} \mathrm{O}_{12}(\mathrm{OH})$ epidote 
Table 9. Estimated bond valence (v.u.)

\begin{tabular}{|c|c|c|c|c|c|c|c|c|c|c|c|}
\hline Sample & Anions & $A 1$ & $A 2$ & $M 1$ & $M 2$ & $M 3$ & Sil & $\mathrm{Si} 2$ & $\mathrm{Si} 3$ & $\Sigma C^{\mathrm{v}}$ & $\begin{array}{l}\text { Anion } \\
\text { chemistry }\end{array}$ \\
\hline \multirow[t]{12}{*}{ CrEpl } & $\mathrm{O} 1$ & $0.25^{*}$ & & $0.45^{*}$ & & $0.28^{*}$ & $0.95^{*}$ & & & 1.93 & $\mathrm{O}^{2-}$ \\
\hline & \multirow{2}{*}{$\mathrm{O} 2$} & & $0.11^{*}$ & & & \multirow[t]{2}{*}{$0.51^{*}$} & & & $1.01^{*}$ & \multirow{2}{*}{1.84} & \multirow{2}{*}{$\mathrm{O}^{2-}$} \\
\hline & & & $0.21^{*}$ & & & & & & & & \\
\hline & $\mathrm{O} 3$ & $0.36^{*}$ & $0.19^{*}$ & & $0.57^{*}$ & & & $1.03 *$ & & 2.15 & $\mathrm{O}^{2-}$ \\
\hline & $\mathrm{O} 4$ & & & $0.59^{\dagger}{ }^{\dagger}$ & & 0.59 & & & & 1.77 & $\mathrm{O}^{2-}$ \\
\hline & O5 & 0.22 & & $0.45^{*^{\dagger}}$ & & & & & 0.90 & 2.02 & $\mathrm{O}^{2-}$ \\
\hline & O6 & 0.11 & & & $0.48^{*^{\dagger}}$ & & & & 0.95 & 2.02 & $\mathrm{O}^{2-}$ \\
\hline & $\mathrm{O} 7$ & 0.43 & 0.46 & & & & 1.15 & & & 2.04 & $\mathrm{O}^{2-}$ \\
\hline & O8 & & $0.06^{*^{\dagger}}$ & & & 0.73 & & 1.07 & & 1.92 & $\mathrm{O}^{2-}$ \\
\hline & O9 & $0.07 *^{\dagger}$ & & & & & 1.01 & 0.97 & & 2.12 & $\mathrm{O}^{2-}$ \\
\hline & $\mathrm{O} 10$ & & 0.20 & & $0.57 *^{\dagger}$ & & & & & 1.34 & $\mathrm{OH}^{-}$ \\
\hline & $\Sigma A^{v}$ & 2.12 & 1.80 & 2.98 & 3.24 & 2.90 & 4.06 & 4.10 & 3.87 & & \\
\hline \multirow[t]{12}{*}{ CrEp2 } & $\mathrm{O} 1$ & $0.25^{*}$ & & $0.46^{*}$ & & $0.27^{*}$ & $0.92 *$ & & & 1.90 & $\mathrm{O}^{2-}$ \\
\hline & \multirow{2}{*}{$\mathrm{O} 2$} & & $0.11^{*}$ & & & \multirow[t]{2}{*}{$0.50^{*}$} & & & $0.98^{*}$ & \multirow{2}{*}{1.81} & \multirow{2}{*}{$\mathrm{O}^{2-}$} \\
\hline & & & $0.22 *$ & & & & & & & & \\
\hline & $\mathrm{O} 3$ & $0.36^{*}$ & $0.18^{*}$ & & $0.57^{*}$ & & & $1.02 *$ & & 2.13 & $\mathrm{O}^{2-}$ \\
\hline & $\mathrm{O} 4$ & & & $0.59^{*}{ }^{\dagger}$ & & 0.58 & & & & 1.76 & $\mathrm{O}^{2-}$ \\
\hline & O5 & 0.21 & & $0.44^{*^{\dagger}}$ & & & & & 0.90 & 1.99 & $\mathrm{O}^{2-}$ \\
\hline & O6 & 0.10 & & & $0.47 *^{\dagger}$ & & & & 0.94 & 1.98 & $\mathrm{O}^{2-}$ \\
\hline & $\mathrm{O} 7$ & 0.41 & 0.45 & & & & 1.17 & & & 2.03 & $\mathrm{O}^{2-}$ \\
\hline & O8 & & $0.06^{*}{ }^{\dagger}$ & & & 0.71 & & 1.07 & & 1.90 & $\mathrm{O}^{2-}$ \\
\hline & O9 & $0.06^{* \dagger}$ & & & & & 0.98 & 0.97 & & 2.07 & $\mathrm{O}^{2-}$ \\
\hline & $\mathrm{O} 10$ & & 0.20 & & $0.55^{*^{\dagger}}$ & & & & & 1.30 & $\mathrm{OH}^{-}$ \\
\hline & $\Sigma A^{v}$ & 2.06 & 1.79 & 2.98 & 3.18 & 2.83 & 3.99 & 4.08 & 3.80 & & \\
\hline \multirow[t]{12}{*}{ CrEp3 } & $\mathrm{O} 1$ & $0.25^{*}$ & & $0.46^{*}$ & & $0.28 *$ & $0.92 *$ & & & 1.91 & $\mathrm{O}^{2-}$ \\
\hline & \multirow{2}{*}{$\mathrm{O} 2$} & & $0.11 *$ & & & \multirow[t]{2}{*}{$0.50^{*}$} & & & $0.99 *$ & \multirow{2}{*}{1.82} & \multirow{2}{*}{$\mathrm{O}^{2-}$} \\
\hline & & & $0.22 *$ & & & & & & & & \\
\hline & $\mathrm{O} 3$ & $0.37 *$ & $0.18^{*}$ & & $0.57^{*}$ & & & $1.01^{*}$ & & 2.13 & $\mathrm{O}^{2-}$ \\
\hline & $\mathrm{O} 4$ & & & $0.59^{*^{\dagger}}$ & & 0.57 & & & & 1.75 & $\mathrm{O}^{2-}$ \\
\hline & O5 & 0.22 & & $0.45^{*^{\dagger}}$ & & & & & 0.88 & 2.00 & $\mathrm{O}^{2-}$ \\
\hline & O6 & 0.10 & & & $0.48^{*^{\dagger}}$ & & & & 0.95 & 2.01 & $\mathrm{O}^{2-}$ \\
\hline & O7 & 0.42 & 0.46 & & & & 1.17 & & & 2.05 & $\mathrm{O}^{2-}$ \\
\hline & $\mathrm{O} 8$ & & $0.06 *^{\dagger}$ & & & 0.71 & & 1.08 & & 1.91 & $\mathrm{O}^{2-}$ \\
\hline & O9 & $0.06^{* \dagger}$ & & & & & 0.98 & 0.98 & & 2.08 & $\mathrm{O}^{2-}$ \\
\hline & $\mathrm{O} 10$ & & 0.21 & & $0.56^{*^{\dagger}}$ & & & & & 1.33 & $\mathrm{OH}^{-}$ \\
\hline & $\Sigma A^{v}$ & 2.10 & 1.81 & 3.00 & 3.22 & 2.84 & 3.99 & 4.08 & 3.81 & & \\
\hline
\end{tabular}

Note: $\Sigma A^{v}$ is the valence of bonds emanating from cation summed over the bonded anions.

$\Sigma C^{v}$ is the valence of bonds reaching anions.

* Two bonds per cation.

${ }^{\dagger}$ Two bonds per anion.

(Giuli et al., 1999) and the synthetic $\mathrm{Ca}_{2}\left(\mathrm{Al}, \mathrm{Mn}^{3+}\right)_{3} \mathrm{Si}_{3} \mathrm{O}_{12}$ $(\mathrm{OH})$ piemontite (Langer et al., 2002; Nagashima and Akasaka, 2004).

As shown in Figure 3, the $M 1^{-} \mathrm{O} 1, M 1^{-} \mathrm{O} 4$ and $M 1^{-}$ $\mathrm{O} 5$ distances increase with the increase of $\mathrm{Cr}^{3+}$ content in the $M 1$ site, and their gradients are similar to each other, indicating an equidimensional expansion of the $M 1 \mathrm{O}_{6}$ octahedra. Although the $M 3 \mathrm{O}_{6}$ octahedra are essentially more distorted than the $\mathrm{MIO}_{6}$ octahedra (Figs. 3 and 4), an almost equidimensional expansion of the $M 3 \mathrm{O}_{6}$ octahedra with the substitution of $\mathrm{Cr}^{3+}+\mathrm{Fe}^{3+}$ for $\mathrm{Al}^{3+}$ is also shown by the similar trends of the variations in $\mathrm{M3}^{-\mathrm{O} 1}$, 


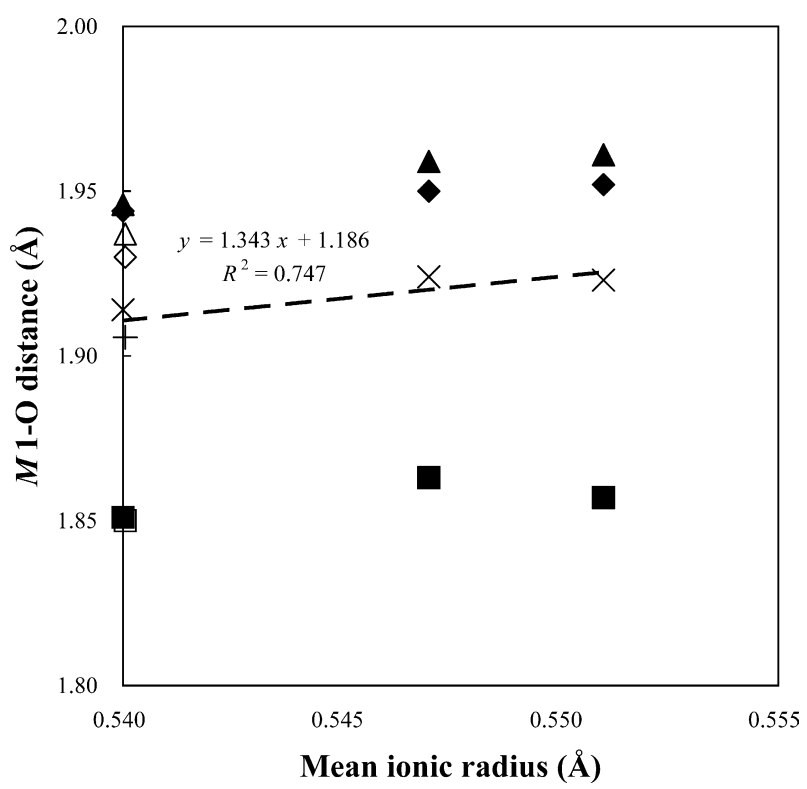

Figure 3. The $M 1^{-} \mathrm{O}$ distances as a function of mean ionic radius. The mean ionic radii were calculated using the ionic radius values of Shannon (1976). Open symbols, clinozoisite (Dollase, 1968); Filled symbols, chromian epidote (this study); Diamond, M1-O1 distance; Square, M1-O4 distance; Triangle, $M 1^{-} \mathrm{O} 5$ distance; $\times$, mean $M 1^{-} \mathrm{O}$ distance of chromian epidote (this study); + , mean M1-O distance of clinozoisite (Dollase, 1968); Broken line, the regression line between the mean $M 1^{-} \mathrm{O}$ distance and the mean ionic radius in chromian epidote (this study) and clinozoisite (Dollase, 1968).

$M 3-\mathrm{O} 2, M 3-\mathrm{O} 4$ and $M 3-\mathrm{O} 8$ lengths as a function of the mean ionic radius (Fig. 4).

Such variations in the $M 1-\mathrm{O} i$ and $M 3-\mathrm{O} i$ distances are also observed in synthetic $\mathrm{Ca}_{2}\left(\mathrm{Al}_{1}, \mathrm{Fe}^{3+}\right)_{3} \mathrm{Si}_{3} \mathrm{O}_{12}(\mathrm{OH})^{-}$ epidote (Giuli et al., 1999). In the synthetic $\mathrm{Ca}_{2}\left(\mathrm{Al}_{1} \mathrm{Mn}^{3+}\right)_{3}$ $\mathrm{Si}_{3} \mathrm{O}_{12}(\mathrm{OH})$-piemontite (Nagashima and Akasaka, 2004), the $M 1 \mathrm{O}_{6}$ and $M 3 \mathrm{O}_{6}$ octahedra expand nonequidimensionally with the substitution of $\mathrm{Mn}^{3+}$ for $\mathrm{Al}$ ions in the $M 1$ and $M 3$ sites due to the Jahn-Teller effect: the $M 1-\mathrm{O} 1$ and $M 3-\mathrm{O} 1$ distances increase more rapidly than other $M 1-\mathrm{O} i(i=4$ and 5) and $M 3-\mathrm{O} i(i=2,4$, and 8$)$ distances, respectively, with the substitution of $\mathrm{Mn}^{3+}$ for $\mathrm{Al}^{3+}$. The nearly equidimensional expansion of the $M 1$ and $M 3$ octahedra caused by the substitution of $\mathrm{Cr}^{3+}$ and/or $\mathrm{Fe}^{3+}$ for $\mathrm{Al}$ is consistent with the fact that $\mathrm{Cr}^{3+}$ and $\mathrm{Fe}^{3+}$ in the octahedral sites do not give rise to a Jahn-Teller distortion.

\section{ACKNOWLEDGMENTS}

The authors thank Prof. Mitsuyoshi Kimata, Mr. Norimasa Nishida, and Ms. Mihoko Hoshino for their guidance and assistance in the X-ray single-crystal analyses at Tsukuba University, Drs. Kazuyoshi Kitajima and Kenji Yoza of Bruker AXS KK for their kind permission

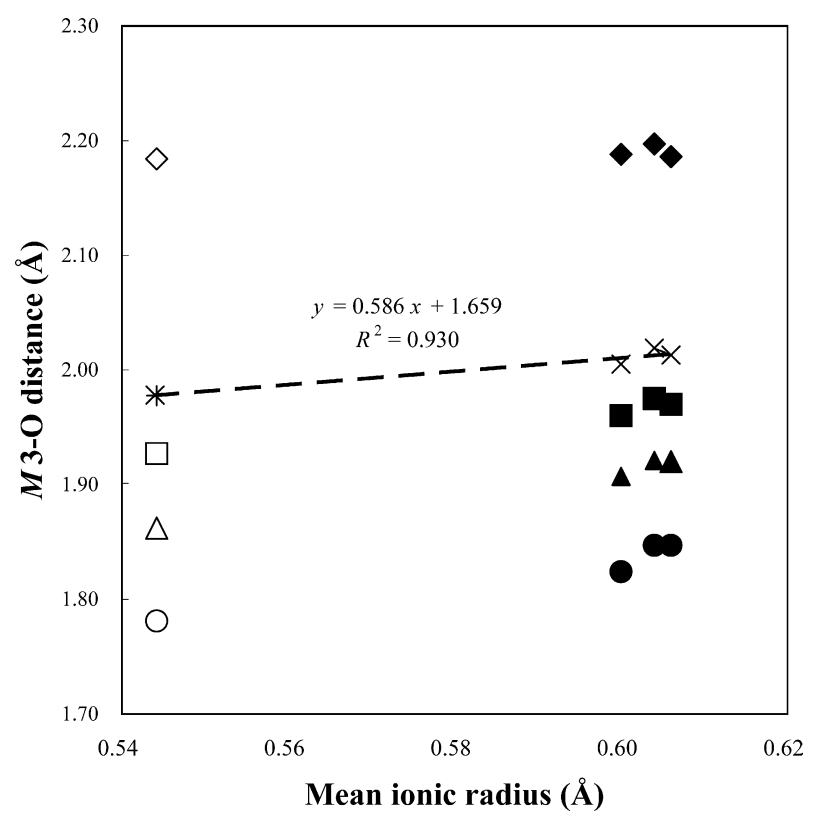

Figure 4. The $M 3-\mathrm{O}$ distances as a function of mean ionic radius. Mean ionic radii were calculated using the ionic radius values of Shannon (1976). Open symbols, clinozoisite (Dollase, 1968); Filled symbols, chromian epidote (this study); Diamond, M3-O1 distance; Square, $M 3-\mathrm{O} 2$ distance; Triangle, $M 3-\mathrm{O} 4$ distance; Circle, $M 3^{-} \mathrm{O} 8$ distance; $\times$, mean $M 3^{-} \mathrm{O}$ distance of chromian epidote (this study); +, mean $M 3-\mathrm{O}$ bond distance of clinozoisite (Dollase, 1968); Broken line, the regression line between the mean $M 3-\mathrm{O}$ bond distance and the mean ionic radius in chromian epidote (this study) and clinozoisite (Dollase, 1968).

to use and help in the X-ray single-crystal analyses using a Bruker SMART APEX CCD diffractometer, Mr. Tsuyoshi Sakurai of Shimane University for providing the samples, Dr. Fujio Izumi of the National Institute for Materials Science for his permission and help in using the RIETAN-2000 program, and to Dr. Barry P. Roser of Shimane University for his critical reading of the manuscript.

\section{REFERENCES}

Akasaka, M. and Shinno, I. (1992) Mössbauer spectroscopy and its recent application to silicate mineralogy. Journal of the Mineralogical Society of Japan. 21, 3-20 (in Japanese with English abstract).

Akasaka, M., Zheng, Y. and Suzuki, Y. (2000) Maximum strontium content of piemontite formed by hydrothermal synthesis. Journal of Mineralogical and Petrological Sciences, 95, 84-94.

Aldridge, L.P., Bancroft, G.M., Fleet, M.E. and Herzberg, C.T. (1978) Omphacite studies, II. Mössbauer spectra of $C 2 / c$ and $P 2 / n$ omphacites. American Mineralogist, 63, 1107-1111.

Armbruster, T., Gnos, E., Dixon, R., Gutzmer, J., Hejny, C., Döbelin, N. And Medenbach, O. (2002) Manganvesuvianite and tweddillite, two new $\mathrm{Mn}^{3+}$-silicate minerals from the 
Kalahari manganese fields, South Africa. Mineralogical Magazine, 66, 137-150.

Bancroft, G.M. and Williams, P.G.L. (1969) Mössbauer spectra of omphacites. Mineralogical Society of America, Special Paper, 2, 50-65.

Bancroft, G.M., Maddock, A.G. and Burns, R.G. (1967) Applications of the Mössbauer effect to silicate mineralogy - I. Iron silicates of known crystal structure. Geochimica et Cosmochimica Acta. 31, 2219-2246.

Bates, T. (1962) Ligand field theory and absorption spectra of transition-metal ions in glasses. In Modern Aspects of the Vitreous State, volume 2 (MacKenzie, J. D. Ed). pp. 260, Butterworths, London, 195-254.

Bird, D.K., Cho, M., Janik C.J., Liou, J.G. and Caruso L.J. (1988) Compositional, order/disorder, and stable isotope characteristics of $\mathrm{Al}-\mathrm{Fe}$ epidote, state 2-14 drill hole, Salton Sea Geothermal System. Journal of Geophysical Research, 93, 13135-13144.

Bonazzi, P., Menchetti, S. and Palenzona, A. (1990) Strontiopiemontite, a new member of the epidote group from Val Graveglia, Liguria, Italy. European Journal of Mineralogy, 2, 519-523.

Bonazzi, P., Garbarino, C. and Menchetti, S. (1992) Crystal chemistry of piemontites: REE-bearing piemontite from Monte Brugiana, Alpi Apuane, Italy. European Journal of Mineralogy, 4, 23-33.

Bonazzi, P. and Menchetti, S. (1994) Structural variations induced by heat treatment in allanite and REE-bearing piemontite. American Mineralogist, 79, 1176-1184.

Bonazzi, P. and Menchetti, S. (1995) Monoclinic members of the epidote group: effects of the $\mathrm{Al} \rightleftarrows \mathrm{Fe}^{3+} \rightleftarrows \mathrm{Fe}^{2+}$ substitution and of the entry of $\mathrm{REE}^{3+}$. Mineralogy and Petrology, 53, 133-153.

Bonazzi, P. and Menchetti, S. (2004) Manganese in monoclinic members of the epidote group: Piemontite and related minerals. In Epidotes (Liebscher, A. and Franz, G. Eds.). pp. 628, Reviews in Mineralogy and Geochemistry 56, Mineralogical Society of America, Washington, D.C., 495-552.

Brese, N.E. and O'Keeffe, M. (1991) Bond-valence parameters for solids. Acta Crystallographica, B47, 192-197.

Brown, I.D. and Shannon, R.D. (1973) Empirical Bond-StrengthBond-Length curves for oxides. Acta Crystallographica, A29, 266-282.

Brown, I.D. and Altermatt, D. (1985) Bond-valence parameters obtained from a systematic analysis of the Inorganic Crystal Structure Database. Acta Crystallographica, B41, 244-247.

Bruker (1999) SMART and SAINT-Plus. Versions 6.01. Bruker AXS Inc., Madison, Wisconsin, USA.

Burns, R.G. and Strens, R.G.J. (1967) Structural interpretation of polarized absorption spectra of the $\mathrm{Al}-\mathrm{Fe}-\mathrm{Mn}-\mathrm{Cr}$ epidotes. Mineralogical Magazine, 36, 204-226.

Clark, J.R., Appleman, D.E. and Papike, J.J. (1969) Crystalchemical characterization of clinopyroxenes based on eight new structural refinements. Mineralogical Society of America, Special Paper, 2, 31-50.

Dollase, W.A. (1968) Refinement and comparison of the structures of zoisite and clinozoisite. American Mineralogist, 53, 1882-1898.

Dollase, W.A. (1969) Crystal structure and cation ordering of piemontite. American Mineralogist, 54, 710-717.

Dollase, W.A. (1971) Refinement of the crystal structures of epidote, allanite and hancockite. American Mineralogist, 56,
447-464.

Dollase, W.A. (1973) Mössbauer spectra and iron distribution in the epidote-group minerals. Zeitschrift für Kristallographie, 138, 41-63.

Dollase, W.A. (1986) Correction of intensities for preferred orientation in powder diffractometry: application of the March model. Journal of Applied Crystallography, 19, 267-272.

Dollase, W.A. and Gustafson, W.I. (1982) ${ }^{57} \mathrm{Fe}$ Mössbauer spectral analysis of the sodic clinopyroxenes. American Mineralogist, 67, 311-327.

Fehr, K.T. and Heuss-Aßbichler, S. (1997): Intracrystalline equilibria and immiscibility along the join clinozoisite-epidote: An experimental and ${ }^{57} \mathrm{Fe}$ Mössbauer study. Neues Jahrbuch für Mineralogie Abhandlungen, 172, 43-67.

Ferraris, G., Ivaldi, G., Fuess, H. and Gregson, D. (1989) Manganese/iron distribution in a strontian piemontite by neutron diffraction. Zeitschrift für Kristallographie, 187, 145-151.

Franz, G. and Liebscher, A. (2004) Physical and chemical properties of the epidote minerals -An Introduction-. In Epidotes (Liebscher, A. and Franz, G. Eds). pp. 628, Reviews in Mineralogy and Geochemistry 56, Mineralogical Society of America, Washington, D.C., 1-81.

Giuli, G., Bonazzi, P. and Menchetti, S. (1999) Al-Fe disorder in synthetic epidotes: A single-crystal X-ray diffraction study. American Mineralogist, 84, 933-936.

Hawthorne, F.C., Ungaretti, L. and Oberti, R. (1995) Site populations in minerals: terminology and presentation of results of crystal-structure refinement. Canadian Mineralogist, 33, 907-911.

Heuss-Aßbichler, S. and Fehr, K.T. (2000) Ein neues Ordnungsmodell für die Mischkristallreihe KlinozoisitEpidot und das Granat-Epidot-Geothermometer. pp. 105. Habilitationthesis, München.

Higashi, T. (1995) Abscor-Empirical correction based on Fourier series approximation. Rigaku Corporation, Tokyo, Japan.

Hoshino, M., Kimata, M., Nishida, N., Kyono, A., Shimizu, M. and Takizawa, S. (2005) The chemistry of allanite from the Daibosatsu Pass, Yamanashi, Japan. Mineralogical Magazine, 69, 403-423.

Ikeda, K. (1984) Crystal-field theory - outlined principle and its application to tetrahedrally coordinated low spin $\mathrm{Cr}^{3+}$ ions. Journal of the Mineralogical Society of Japan. 16, 385-401 (in Japanese with English abstract).

Ikeda, K. and Ohashi, H. (1974) Crystal field spectra of diopsidekosmochlor solid solutions formed at $15 \mathrm{~kb}$ pressure. The Journal of the Japanese Association of Mineralogists, Petrologists and Economic Geologists, 69, 103-109.

Ikeda, K., Schneider, H., Akasaka, M. and Rager, H. (1992) Crystal-field spectroscopic study of $\mathrm{Cr}$-doped mullite. American Mineralogist, 77, 251-257.

Ito, T., Morimoto, N. and Sadanaga, R. (1954) On the structure of epidote. Acta Crystallographica, 7, 53-59.

Izumi, F. and Ikeda, T. (2000) A Rietveld-analysis program RIETAN-98 and its application to zeolites. Material Science Forum, 321-324, 198-203.

Kvick, A., Pluth, J.J., Richardson, J.W. and Smith, J.V. (1988) The ferric ion distribution and hydrogen bonding in epidote: a neutron diffraction study at $15 \mathrm{~K}$. Acta Crystallographica, B44, 351-355.

Langer, K., Tillmanns, E., Kersten, M., Almen, H. and Arni, R.K. (2002) The crystal chemistry of $\mathrm{Mn}^{3+}$ in the clino- and orthozoisite structure types, $\mathrm{Ca}_{2} \mathrm{M}_{3}^{3+}\left[\mathrm{OH} / \mathrm{O} / \mathrm{SiO}_{4} / \mathrm{Si}_{2} \mathrm{O}_{7}\right]$ : A 
structural and spectroscopic study of some natural piemontites and "thulites" and their synthetic equivalents. Zeitschrift für Kristallographie 217, 1-18.

Lavina, B., Carbonin, S., Russo, U. and Tumiati, S. (2006) The crystal structure of dissakisite-(La) and structural variations after annealing of radiation damage. American Mineralogist, 91, 104-110.

Liebscher, A. (2004) Spectroscopy of epidote minerals. In Epidotes (Liebscher, A. and Franz, G. Eds). pp. 628, Reviews in Mineralogy and Geochemistry 56, Mineralogical Society of America, Washington, D.C., 125-170.

Merli, M., Oberti, R., Caucia, F. and Ungaretti, L. (2000) Determination of site population in olivine: Warnings on $\mathrm{X}^{-}$ ray data treatment and refinement. American Mineralogist, $85,55-65$.

Miyajima, H., Matsubara, S., Miyawaki, R. and Hirokawa, K. (2003) Niigataite, $\mathrm{CaSrAl}_{3}\left(\mathrm{Si}_{2} \mathrm{O}_{7}\right)\left(\mathrm{SiO}_{4}\right) \mathrm{O}(\mathrm{OH})$ : $\mathrm{Sr}$-analogue of clinozoisite, a new member of the epidote group from the Itoigawa-Ohmi district, Niigata Prefecture, central Japan. Journal of mineralogical and petrological sciences, 98, 118129.

Mottana, A., Rossi, G., Kracher, A. and Kurat, G. (1979) Violan revisited: Mn-bearing omphacite and diopside. Mineralogy and Petrology, 26, 187-201.

Nagashima, M. and Akasaka, M. (2004) An X-ray Rietveld study of piemontite on the join $\mathrm{Ca}_{2} \mathrm{Al}_{3} \mathrm{Si}_{3} \mathrm{O}_{12}(\mathrm{OH})-\mathrm{Ca}_{2} \mathrm{Mn}_{3}^{3+}$ $\mathrm{Si}_{3} \mathrm{O}_{12}(\mathrm{OH})$ formed by hydrothermal synthesis. American Mineralogist, 89, 1119-1129.

Nagashima, M., Akasaka, M. and Sakurai, T. (2006) Chromian epidote in omphacite rocks from the Sambagawa metamorphic belt, central Shikoku, Japan. Journal of Mineralogical and Petrological Sciences, 101, 157-169.

Paesano, A., Kunrath, J.I. and Vasquez, A. (1983) A ${ }^{57} \mathrm{Fe}$ Mössbauer study of epidote. Hyperfine Interactions, 15/16, 841844.

Shannon, R.D. (1976) Revised effective ionic radii and systematic studies of interatomic distances in halides and chalcogenides. Acta Crystallographica, A32, 751-767.

Sheldrick, G.M. (1996) SADABS. University of Göttingen, Germany.

Sheldrick, G.M. (1997) SHELXL97 program for the refinement of crystal structures and SHELXS97 program for the solution of crystal structures. University of Göttingen, Germany.

Shepel, A.B. and Karpenko, M.V. (1969) Mukhinite, a new variety of epidote. Doklady Akademii Nauk SSSR, 185, 13421345 (in Russian).

Treloar, P. (1987) Chromian muscovites and epidotes from Outokumpu, Finland. Mineralogical Magazine, 51, 593-599.

White, W.B., McCarthy, G.J. and Scheetz, B.E. (1971) Optical spectra of chromium, nickel and cobalt-containing pyroxenes. American Mineralogist, 57, 1692-1710.

Yang, J.J. and Enami, M. (2003) Chromian dissakisite-(Ce) in a garnet lherzolite from the Chinese $\mathrm{Su}-\mathrm{Lu}$ UHP metamorphic terrane: Implications for $\mathrm{Cr}$ incorporation in epidotegroup minerals and recycling of REE into the Earth's mantle. American Mineralogist, 88, 604-610.

Manuscript received March 10, 2006

Manuscript accepted February 11, 2007

Manuscript handled by Kazumasa Sugiyama 